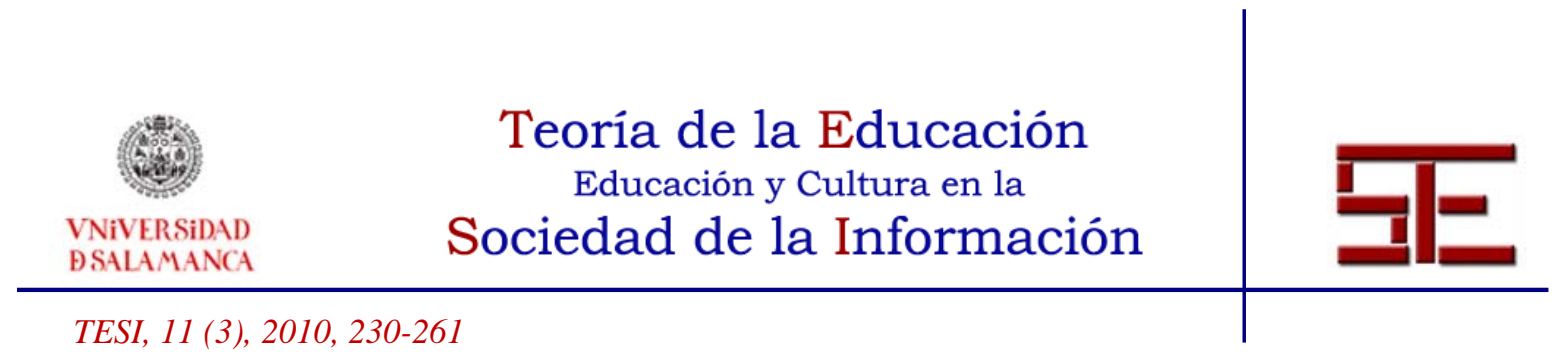

\title{
¿QUÉ HACEN LAS ESCUELAS INNOVADORAS CON LA TECNOLOGÍA?: LAS TIC AL SERVICIO DE LA ESCUELA Y LA COMUNIDAD EN EL COLEGIO AMARA BERRI
}

\section{Resumen:}

La utilización de las tecnologías digitales exige una reflexión pedagógica que oriente y guíe su integración en las actividades escolares. Las TIC (Tecnologías de la Información y la Comunicación) tienen reconocido todo su potencial pero son grandes también las limitaciones de su impacto. El análisis de buenas prácticas con TIC desarrollado dentro del proyecto de investigación titulado "Análisis de las políticas educativas de las TIC en los centros escolares y sus efectos sobre la innovación

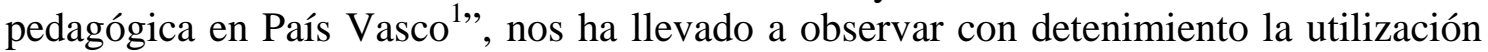
de la tecnología digital en el Colegio Amara Berri de San Sebastián, un centro de reconocida tradición e influencia innovadora. Describimos las actividades del departamento de Medios de Comunicación (Hedabideak), los diferentes talleres y su organización, las tareas y proyectos que allí se realizan, así como los roles de maestros y alumnos. Por último, finalizamos valorando la experiencia desde un punto de vista pedagógico.

Palabras clave:

Educación Primaria, tecnologías digitales, innovación, buenas prácticas, medios de comunicación.

\footnotetext{
${ }^{1}$ Proyecto de investigación: “Análisis de las políticas educativas de las tic en los centros escolares y sus efectos sobre la innovación pedagógica en País Vasco” (SEJ2006-12435-C05-02).
}

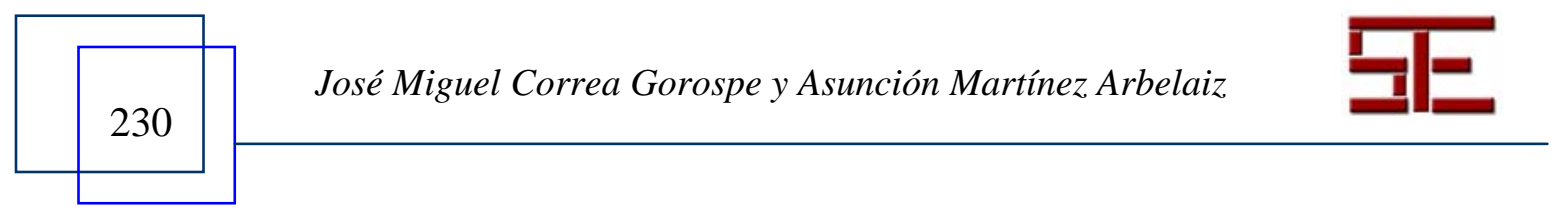




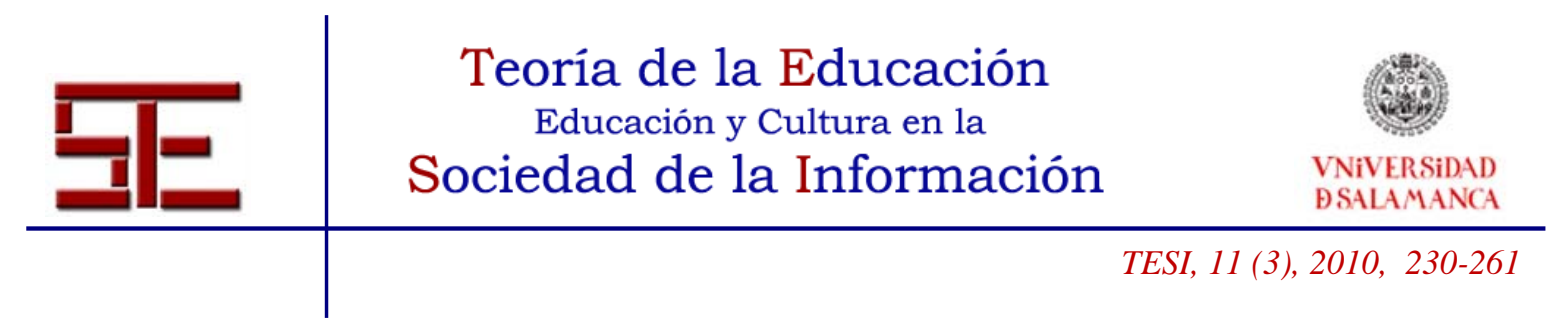

\title{
WHAT DO INNOVATIVE SCHOLS DO WITH TECHNOLOGY?: ICT SERVING THE SCHOOL AND THE COMMUNITY IN THE AMARA BERRI SCHOOL
}

\begin{abstract}
:
The use of digital technologies requires careful thinking that organizes and guides their integration into school activities. ICT (Information and Communication Technologies) have a recognized potential but their actual impact has serious limitations. The analysis of good practices with ICT has been developed within the research project entitled "Analysis of educational policies regarding ICT in schools and their effects on pedagogical innovation in the Basque Country" and it has made us pay special attention to the use of digital technologies in the Colegio Amara Berri from San Sebastián, a school with a long and well-deserved reputation for innovation. We describe the activities in the department of Mass Media (Hedabideak), its different workshops and their organization, its tasks and projects, as well as the roles of teachers and students. Finally, we end up assessing the experience from a pedagogical point of view.
\end{abstract}

Key words:

Primary education, digital technologies, innovation, good practices, mass media.

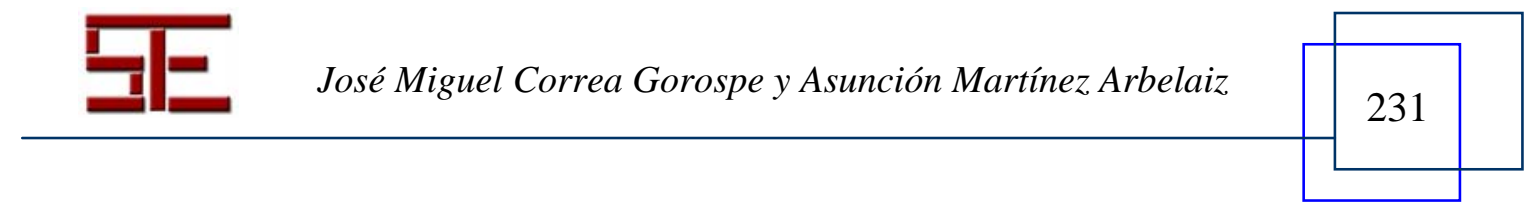




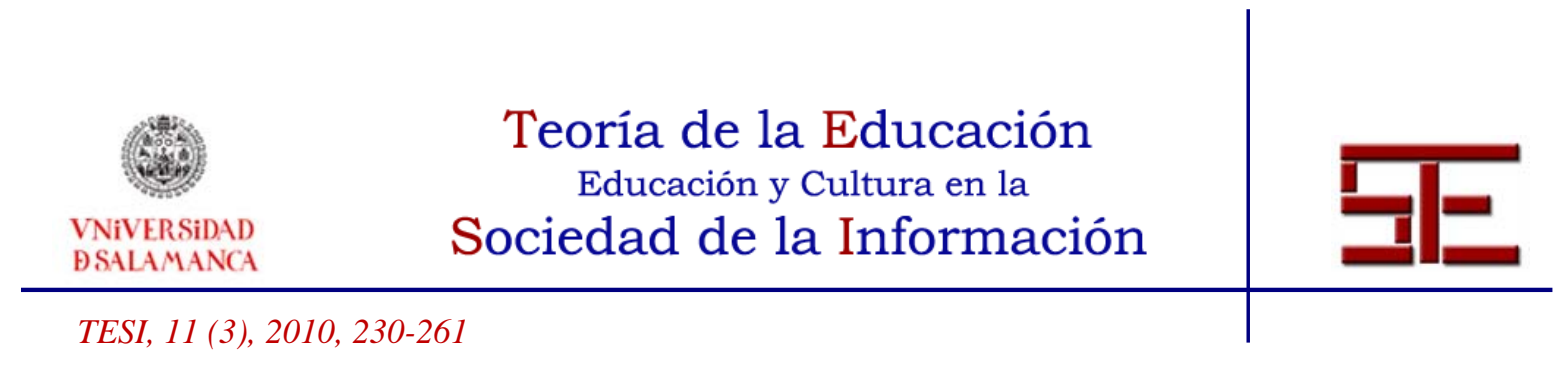

¿QUÉ HACEN LAS ESCUELAS INNOVADORAS CON LA TECNOLOGÍA?: LAS TIC AL SERVICIO DE LA ESCUELA Y LA COMUNIDAD EN EL COLEGIO AMARA BERRI

Fecha de recepción: 15/02/2009; fecha de aceptación: 15/12/2009; fecha de publicación: 28/02/10

José Miguel Correa Gorospe

jm.correagorospe@ehu.es

Universidad del País Vasco

Asunción Martínez Arbelaiz

am15@cornell.edu

University Studies Abroad Consortium

\section{1.- INTRODUCCIÓN}

La introducción de las TIC en el contexto educativo no ha dado el impulso esperado a la pedagogía ni ha estimulado lo suficiente al sistema escolar en la búsqueda de nuevos caminos para enseñar y aprender, apoyándose en las posibilidades de las tecnologías.

Aunque la relación entre la tecnología y la innovación educativa (Kozma \& Anderson, 2002) es importante, y estamos de acuerdo con Dede (2001) en que las TIC apropiadamente programadas e implementadas tienen el potencial de revolucionar la enseñanza y mejorar el aprendizaje con la misma profundidad que han revolucionado otros ámbitos y aunque se están haciendo importantes inversiones en infraestructuras tecnológicas para la escuela y elaborando políticas y planes estratégicos para la integración de las tecnologías en el sistema escolar, su impacto en las escuelas está siendo bastante limitado, no llegando a las aulas los cambios esperados ni a lo que en ellas hacen estudiantes y profesores.

Se asocia actualmente el uso o presencia de las TIC con la temática de la innovación y de la calidad, aunque se ha demostrado que el cambio no sólo depende de la tecnología sino de la modificación de las relaciones entre los docentes, los alumnos, la información y la experiencia (Riel, 2000). Su incorporación en la institución escolar está ligada al problema de la sostenibilidad y escalabilidad de las innovaciones educativas, exigiendo atención a aspectos no sólo tecnológicos sino también, y sobre todo, didácticos y organizativos. Parece claro que el uso de las computadoras por sí solo no produce

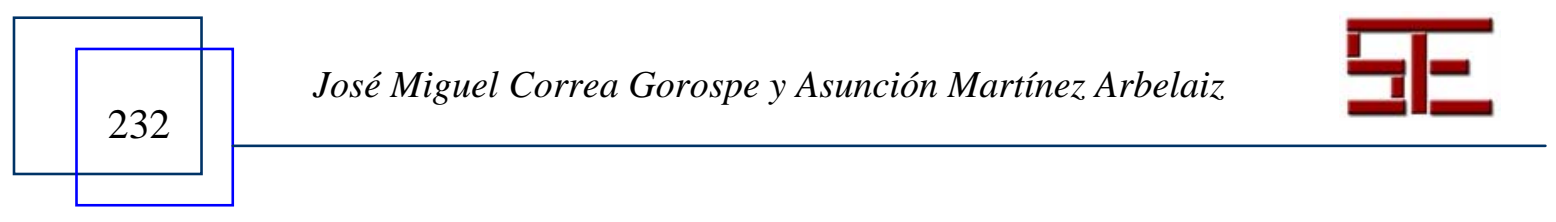




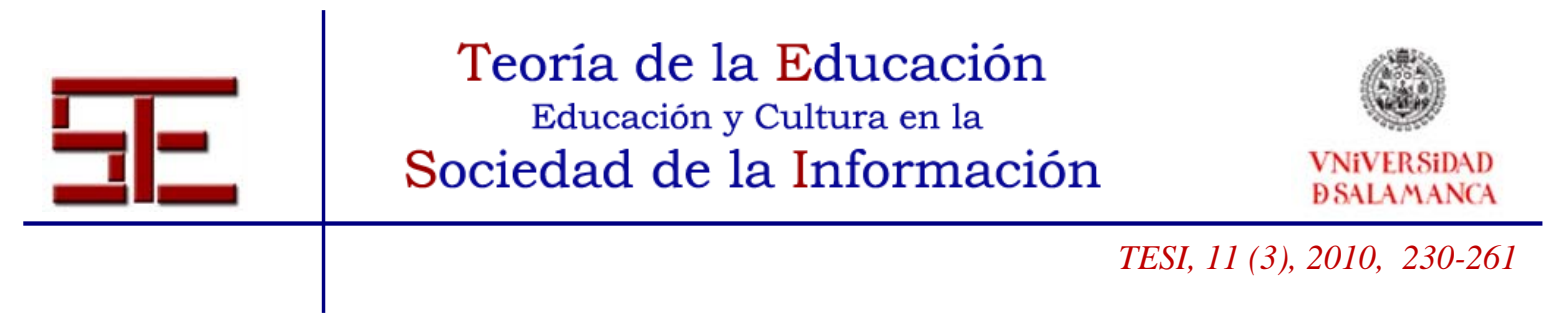

innovación. Pese a todo, hay depositadas profundas expectativas en el uso de la nueva tecnología.

Sin embargo, sí es cierto que las TIC están cambiando profundamente nuestra sociedad, el conocimiento y las demandas y expectativas sobre la escuela y lo que de ella se espera. La incorporación de las TIC no es sólo un problema de equipamiento ni de formación del profesorado; estamos viviendo, en definitiva, la contradicción señalada por Hargreaves (2003) de no permitir que las escuelas eduquen al alumnado para la Sociedad del Conocimiento:

"De forma paradójica, en un momento en el que en todos los ámbitos de la sociedad se valora el ingenio y la inventiva, en la escuela se fomenta la homogeneidad. Cuando se defiende la desregulación como forma de hacer aflorar la creatividad, la escuela se ve cada vez más regulada y con menos espacio para abordar su propia transformación” (Sancho, 2005).

\section{2.- LAS LIMITACIONES DEL IMPACTO DE LAS TIC}

Al hacer una revisión bibliográfica sobre el impacto de las TIC en las escuelas, uno de los temas que más nos han interesado ha sido identificar las limitaciones de las TIC descritas en la bibliografía pedagógica (European Schoolnet, 2006). Es interesante, desde nuestro punto de vista, saber qué es lo que ocurre cuando lo que se había prometido era tanto y los logros tan escasos, sobre todo cuando los intereses comerciales acechan detrás de las promesas pedagógicas.

Los estudios de impacto han identificado las principales barreras que impiden una integración más exitosa de las TIC y lograr un mayor impacto. Se pueden agrupar en barreras a nivel profesorado (nivel micro), barreras a nivel escuela (nivel meso) y barreras a nivel sistema (nivel macro) (ver Balankat et al., 2006).

En el nivel micro la falta de habilidades TIC de los profesores y la puesta al día de estas habilidades sigue siendo una de las principales barreras, ya que afecta a la elección de los profesores de una tecnología dada. Esto influye en su capacidad para adoptar nuevas prácticas pedagógicas con TIC. A nivel de escuela, la infraestructura TIC y el acceso a las TIC sigue siendo un tema principal. Tal y como a menudo se ha mostrado, la disponibilidad de la tecnología no es el único factor para lograr una integración exitosa de las TIC, pero su ausencia o poca calidad debido a un mantenimiento insuficiente es un obstáculo crucial. Las escuelas sin suficientes recursos claramente están perdiendo las oportunidades que las TIC pueden ofrecer. Otras barreras intrínsecas a nivel escuela son la organización, relacionada con los temas de liderazgo y la estrategia para las TIC. La última evidencia muestra que las estrategias TIC, para ser efectivas, deben estar integradas en la visión de conjunto de la escuela.

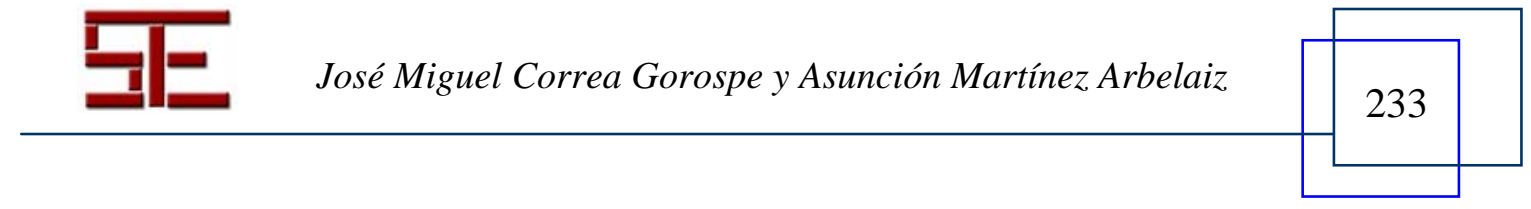




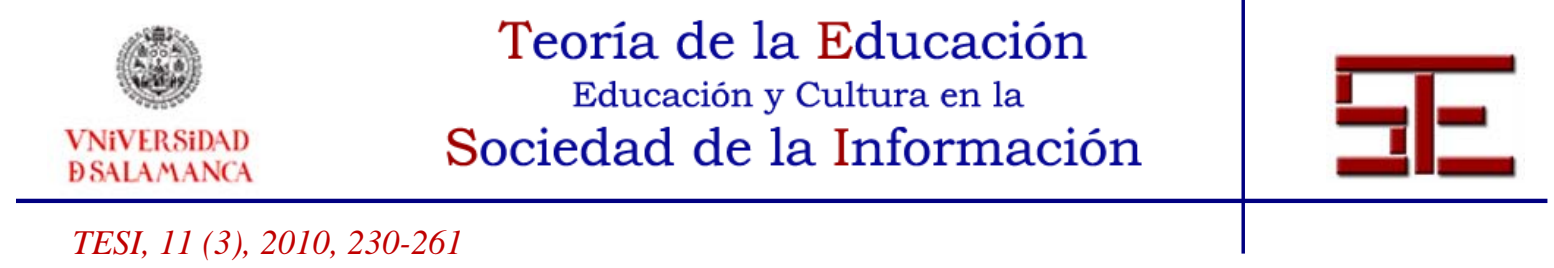

La evidencia también muestra la recurrente reivindicación de reducción de las barreras a nivel de sistema, principalmente en relación a los métodos de valoración y evaluación de los resultados existentes, los cuales no tienen en cuenta las nuevas competencias adquiridas al utilizar las TIC en el aprendizaje. Los profesores están bajo presión para alcanzar los objetivos estándar y temen que las escuelas que utilizan TIC tengan un menor rendimiento que las escuelas tradicionales.

Un repaso a los principales estudios que se están haciendo en Europa arroja muchas matizaciones sobre el uso y eficacia demostrada de la integración de las TIC en las aulas. Nos gustaría destacar tres ideas reiteradas en otros muchos estudios y que Balaskat et al (2006) recogen. Primero la descompensación entre inversiones y beneficios. En segundo lugar, que la práctica de los profesores no está cambiando demasiado al utilizar TIC. Y tercero, que los sistemas educativos actuales dificultan el impacto de las TIC.

\section{3.- BUENAS PRÁCTICAS CON TECNOLOGÍA}

Aparte de sus ventajas y utilidades no podemos olvidar los intereses económicos que tienen asociados (ver Apple, 1997) y su funciones de control y reproducción cultural (ver Haraway, 1995; Gee, Hull \& Lankshear, 2002), los problemas profesionales de su integración en el sistema escolar (por ejemplo, la intensificación del trabajo de los docentes) y el modelo de educación transmisiva y tradicional que muchas veces contribuyen a legitimar.

Por todo ello, es importante cuestionarse la relevancia social y el papel que está desempeñando la tecnología en las instituciones escolares para desvelar y problematizar sus funciones y los objetivos que están cumpliendo. La integración de las tecnologías en la educación no sólo ha afectado a aspectos relacionados con la docencia directa en las aulas, la gestión educativa de los centros y las comunicaciones con la comunidad; también han aparecido, gracias a la necesidad de infraestructuras tecnológicas, nuevas oportunidades de negocio, donde antes parecía impensable (por ejemplo, pizarras digitales, ordenadores, contenidos digitales, conectividad a Internet, formación digital, asesoría). Son éstas necesidades reales y sentidas, pero nunca hasta ahora tan relevantes económicamente.

De las ventajas, características y principales transformaciones que las TIC han traído consigo, tenemos buena referencia en textos que han analizado el problema de las buenas prácticas con tecnología (ver De Pablos, 2007; Area, 2007), identificando los principales ámbitos de influencia y sugiriendo definiciones inclusivas.

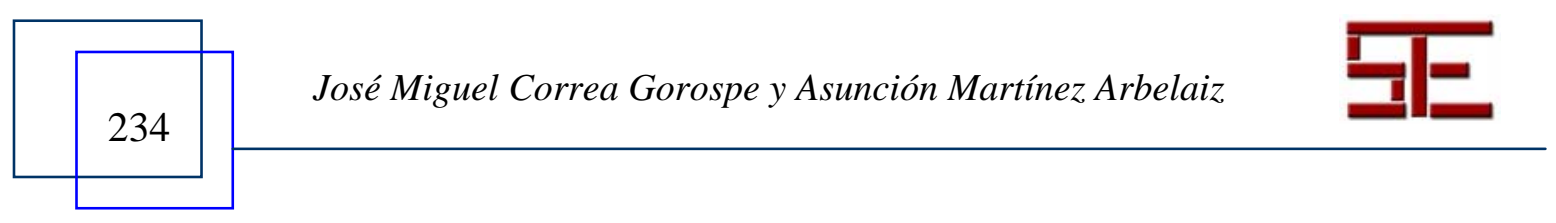




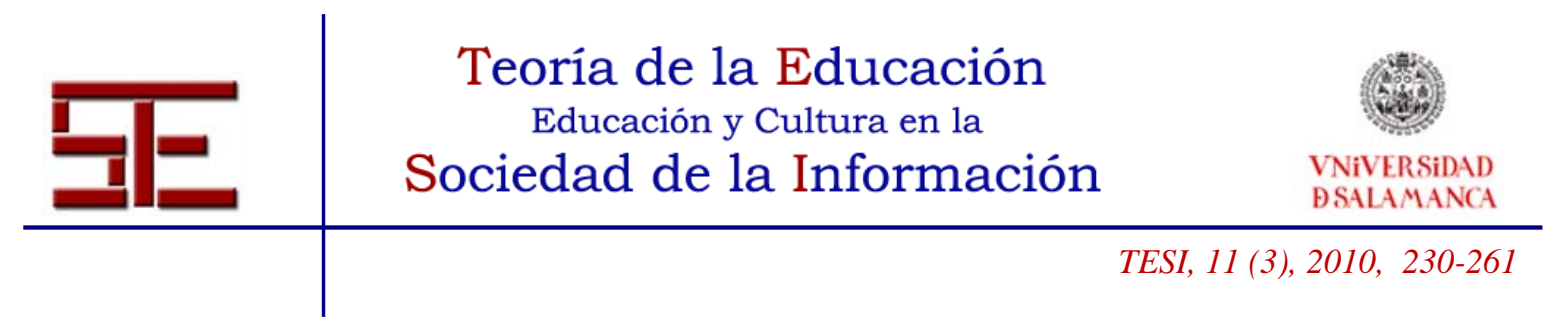

Como investigadores, a nosotros nos interesa analizar y comprender no sólo los aspectos positivos de las tecnologías y su impacto educativo, también los problemas que plantea su integración en las aulas y comprender qué contribuye a legitimar o deslegitimar su uso (Kincheloe, 2008).Básicamente, nuestro interés al dar una definición de buenas prácticas es clarificar qué tipo de escuela y educación necesitamos y desde este perfil identificar y problematizar el papel de la tecnología y el significado de las buenas prácticas con TIC. Las buenas prácticas con TIC, no sólo implican a las tecnologías sino al conjunto de indicadores pedagógicos de la experiencia educativa a la que hacen referencia y a las finalidades de la Escuela como institución.

Las tecnologías han supuesto para el profesor un proceso de reinstrumentalización profesional artificial y mecanizado, útil muchas veces para reforzar, mejorar y rentabilizar su papel transmisivo y reproductor, sin cuestionarse ni problematizar o indagar en profundidad el significado del modelo de ciudadanía educada que estamos contribuyendo a formar. La actividad escolar está llena de ejemplos de incorporación de los últimos artefactos tecnológicos aparecidos en el mercado para seguir haciendo lo mismo (ver Sancho, 2005). Además, como dice Siraj-Blatchford $(2005,11)$

"gran parte de la investigación sobre las TIC se ha centrado exclusivamente en el análisis de su eficacia para alcanzar los objetivos tradicionales del aprendizaje. Sin desarrollar perspectivas o líneas de trabajo con tecnologías que sirvan para desarrollar la creatividad, expresión personal y aprender a aprender, apoyando las capacidades infantiles de creatividad y pensamiento crítico”.

Viendo el potencial de la tecnología pero intentando explicar su falta de rentabilidad en las escuelas y comparándola con otras experiencias extraescolares (ver Martínez Arbelaiz y Correa Gorospe, 2009) atribuíamos a la Gramática de la Escuela (ver Tyack y Tobin, 1992) parte de ese fracaso. Estas limitaciones tienen que ver mucho con la cultura escolar y con la mentalidad del profesorado: las maneras de concebir el currículo, el papel del profesor (su autoridad, poder y control) y del alumno y la forma de conectar sus intereses; la distribución del espacio y del tiempo, la homogeneidad de los agrupamientos, las extendidas dicotomías de quién sabe y quién aprende; la permanencia de los tradicionales libros de texto y la identidad de las tareas de aprendizaje; los estándares de evaluación y niveles de logro y de otros anclajes fundamentales de la enseñanza tradicional. Esta visión de la enseñanza tradicional y su visión y práctica alternativa nos ayudan a comprender y representar también las buenas prácticas. Como también y en profundidad han explicado otros autores como Lankshear y Knobel $(2008,66)$

"El aprendizaje escolar es aprendizaje para la escuela; para la escuela como ha sido siempre. El pujante ascenso de las nuevas tecnologías nos ofrece sencillamente nuestra

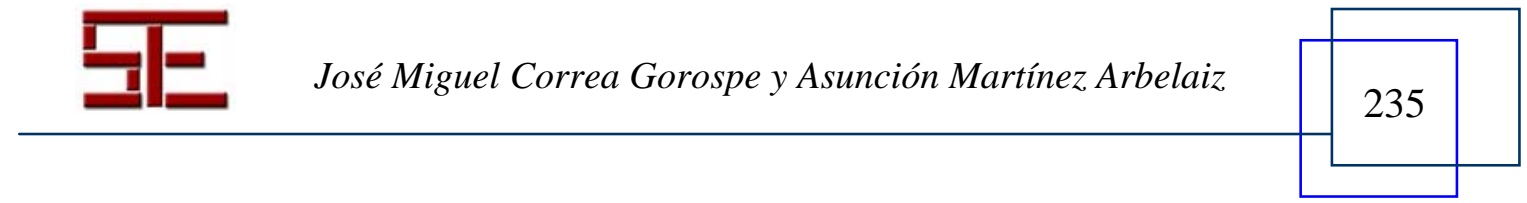




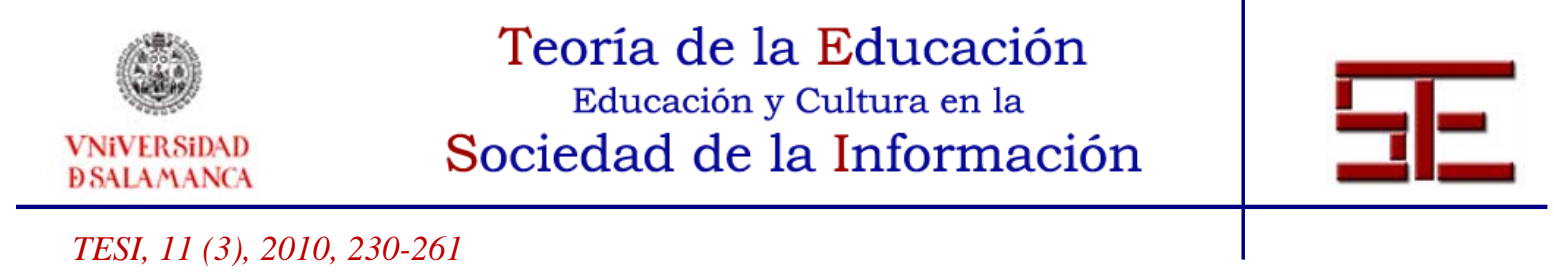

última "posición" sobre este fenómeno. Es la verdad que subyace a muchas afirmaciones actuales de que el aprendizaje escolar choca con las auténticas formas de aprendizaje y de estar en el mundo y con las prácticas sociales que se desarrollan fuera de la escuela. La razón por la que muchas apropiaciones escolares de las nuevas tecnologías parezcan raras en relación con las prácticas del mundo real con que los niños se sienten a menudo a gusto y cómodos tiene que ver con esta lógica. Precisamente esta gramática profunda de la escuela separa los centros escolares de los nuevos alfabetismos (tecnológicos) y de las subjetividades con ellos relacionadas a las que están obligados a prestar atención los educadores”.

Por otro lado, desde muchas instancias (OCDE, UNESCO, Comisión Europea) se demanda a la escuela que adopte otra manera de enseñar y que abandone los modelos tradicionales. Las TIC y la sociedad de la información han creado un escenario que se debate entre reinstrumentalizar al profesorado con competencias digitales para continuar haciendo lo mismo, pero más intensivamente, o esperar un renacimiento del docente como profesional reflexivo, innovador y transformador de su práctica, capaz de romper la lógica escolar (Fisher, Higgins \& Loveless, 2007), respondiendo así al reto de las nuevas demandas sociales y los objetivos educativos y compromisos que se exige de las escuelas.

Pérez Gómez (2008, 63) señala que:

"las nuevas exigencias y condiciones de la sociedad basada en la información remueven drásticamente los fundamentos de la escuela clásica y de sus modos de entender el conocimiento, así como la formación personal, social y profesional de los ciudadanos contemporáneos."

Al referirse a los retos que tiene planteada la Escuela y las competencias clave del proyecto DeSeCo de la OCDE, comenta que:

“Adoptar las competencias llave o básicas ha de suponer un cambio sustancial en las formas de enseñar, aprender y evaluar. No es una modificación cosmética y superficial. Supone establecer el aprendizaje activo de conocimiento útil como el centro de la vida escolar, lo que significa una trasformación radical de la forma de concebir el currículum, los procesos de enseñanza-aprendizaje y evaluación, la organización de los contextos escolares y la propia función docente. [...] Y que no vale cualquier tipo de enseñanza sino aquella que facilita y estimula el aprendizaje de las competencias y cualidades humanas consideradas como valiosa." $(2008,87)$.

Cuando habla de los cambios fundamentales que han de darse en los centros escolares señala que:

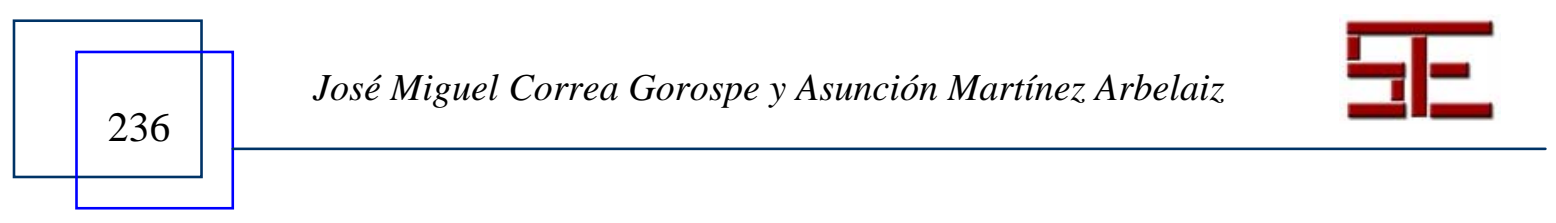




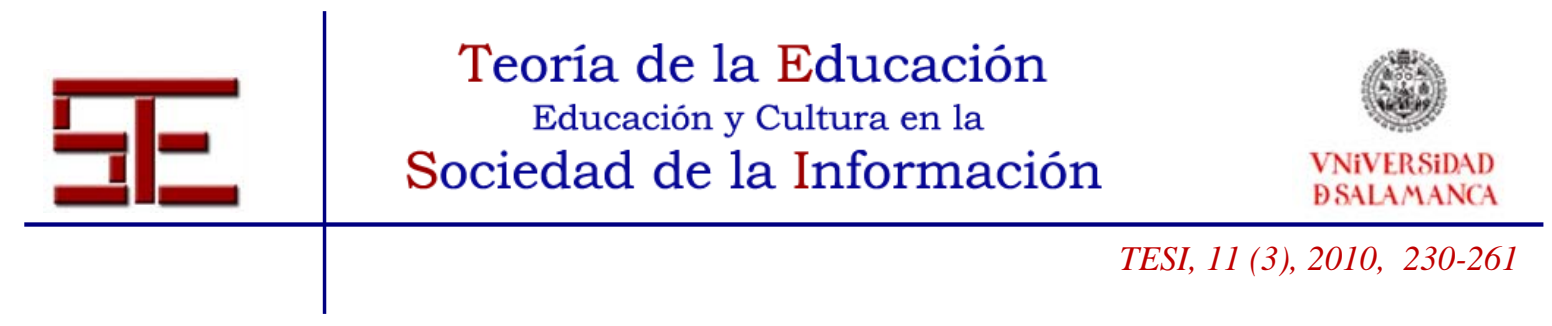

"han de afectar seriamente a los modos de concebir el espacio, el tiempo y las relaciones sociales. La escuela concebida como comunidad de aprendizaje no puede establecer agrupamientos rígidos y cerrados por edades o por capacidades, sino escenarios abiertos de interacciones múltiples horizontales y verticales. Del mismo modo no tienen sentido los horarios fragmentados habituales, ni los espacios cerrados y rígidos que inducen metodologías transmisivas, unidireccionales y frecuentemente pasivas desde el punto de vista de los estudiantes. Un currículum flexible, dinámico y centrado en el aprendizaje activo del estudiante requiere contextos abiertos, flexibles y estrechamente relacionados con la comunidad social, laboral y cultural y con los espacios naturales que rodean la escuela” (Pérez Gómez, 2008, 93).

Por todo ello, las buenas prácticas educativas -con o sin tecnología-, desde nuestro punto de vista, son aquellas que cuestionan el orden establecido de la escuela tradicional. Estas buenas prácticas son visibles dentro de otro marco de actuación docente y cultura escolar y conllevan inevitables rupturas con las formas tradicionales de enseñar. Como bien ha explicado Hernández (en Area, 2007):

"En mi caso, y desde el proyecto de pensar otra narrativa para la Escuela en el que participo, considero que una buena práctica es aquella que:

(a) permite que todos los aprendices encuentren su lugar para aprender;

(b) favorece formas de aprendizaje vinculadas a la comprensión y no a la repetición;

(c) tiende a cuestionar lo establecido más que a naturalizarlo;

(d) quienes lo practican saben dar razones del por qué lo hacen;

(e) favorece la creación de conocimiento a partir del diálogo y el debate desde posiciones no siempre coincidentes;

( $f$ ) permite establecer relaciones entre campos u objetos que se han mantenido aislados; $y$

(g) (y la lista se puede alargar) se da cuenta de todo el proceso seguido utilizando diferentes alfabetismos."

Esta ruptura epistemológica tan constantemente reclamada a la escuela desde el siglo pasado, desde distintas voces e instituciones, supone un proceso de deconstrucción de la escuela y de la cultura escolar, de la metodología y también de la finalidad del aprendizaje escolar, donde las posibilidades de las tecnologías digitales actuales, así como otro tipo de experiencias extraescolares, ayudan a cuestionarse el modelo.

"La escuela necesita una nueva narrativa que replantee su propósito. Una narrativa que dé otro sentido a la relación pedagógica. Que quiebre la propuesta de que para aprender se necesita un espacio cerrado, donde un grupo de edad gire en torno a una sola persona y a los libros de texto. Donde los tiempos no queden anclados por las

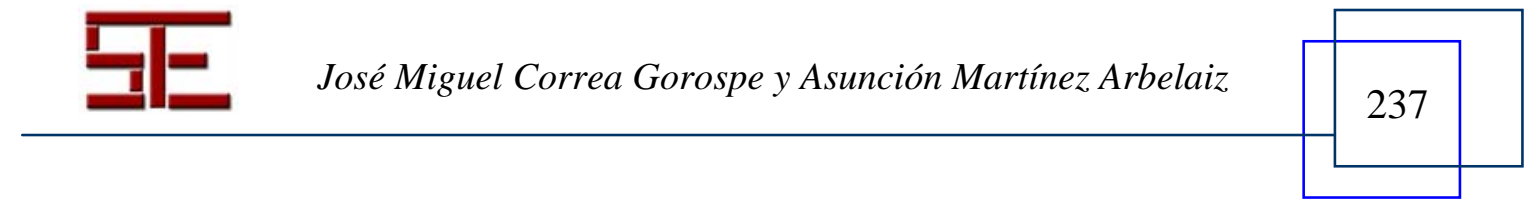




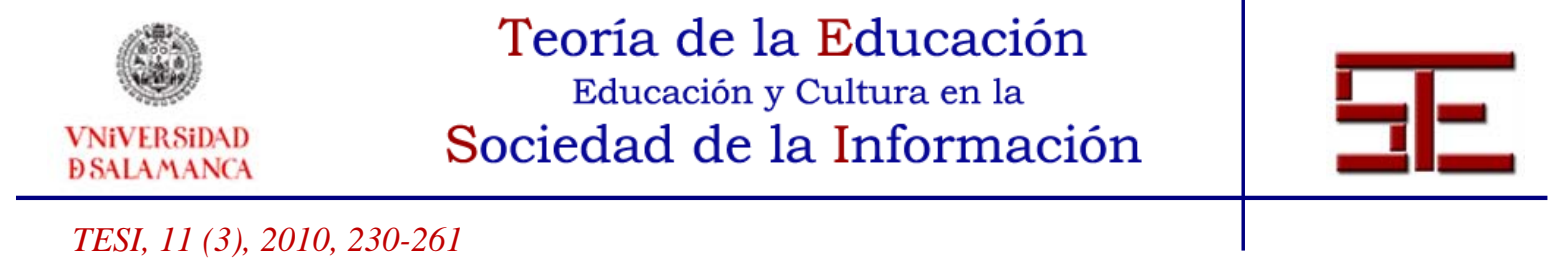

asignaturas o las especialidades de los docentes. Donde el dentro y fuera se diluyan y los límites se hagan permeables. Una narrativa que haga de su colaboración su bandera y de la aventura de la indagación su meta. En la que aprender sea un proceso apasionante que conecte con el sentido de ser de los aprendices y no sólo se dirija hacia sus mentes y su razón. Donde poner el saber en ciclo sea el propósito del viaje y no la llegada al puerto del examen. Donde todo se haga visible al mundo y se aprenda a ser libre y a tener criterio. En esa narrativa, las TIC ejercen un papel como medio de reflexionar sobre la información a la que se accede y como posibilidad para aprender con otros" (Hernández, 2006, 68).

Por todo lo anterior que hemos planteado, nuestro interés se ha centrado en identificar buenas prácticas educativas con tecnología innovadoras que, de manera sistemática, sostenida y escalable supongan alternativas profundas al modelo tradicional de escolaridad. Somos conscientes de que las experiencias de innovación, para que cumplan estas características, requieren una perspectiva pedagógica madurada y compartida no provocada ni accesible por la exclusiva incorporación de artefactos tecnológicos. A menudo se dan y/o coexisten experiencias TIC esporádicas en centros educativos que suponen una ruptura con las formas tradicionales de enseñanza, aun sin llegar a sostenerse temporalmente. Debemos reconocer el valor de estas rupturas ocasionales del orden escolar establecido y, a la vez, considerando la complejidad de la realidad educativa y de los procesos de innovación con o sin tecnología, podemos afirmar que, en ciertas ocasiones, estas prácticas aportan interferencias liberadoras que permiten al profesorado explorar nuevas dimensiones de su trabajo.

La escuela tiene que replantearse cómo se ha naturalizado un discurso y uso tecnológico reproductor de las prácticas tradicionales de enseñanza y cómo contribuye a fortalecer la persistencia de un currículo hegemónico y tiene que pasar a promover estrategias alternativas, situadas, abiertas a la comunidad, solidarias y cooperativas que acompañen a esa trasformación necesaria del papel que las escuelas desempeñan en nuestra sociedad (ver Rodríguez Romero, 2006). En esta capacidad de generar unas prácticas curriculares antihegemónicas (Kincheloe, 2008) hay que situar los criterios de calidad y distinción de las buenas prácticas con TIC.

En este sentido, en la Escuela Pública Amara Berri identificamos ciertas características innovadoras (aprendizaje comunitario, situado, cooperativo y auténtico), asociadas con un tipo de enseñanza alternativo al modelo de escuela tradicional. Estas características conforman un sistema que se ha mostrado sostenible y escalable. Entre estas características distintivas podríamos señalar: la conexión de los intereses de los escolares con las tareas académicas, el protagonismo del alumno, el aprendizaje centrado en el grupo cooperativo y en la responsabilidad social, el desarrollo de proyectos, la enseñanza situada basada en la investigación del medio, el desarrollo de la

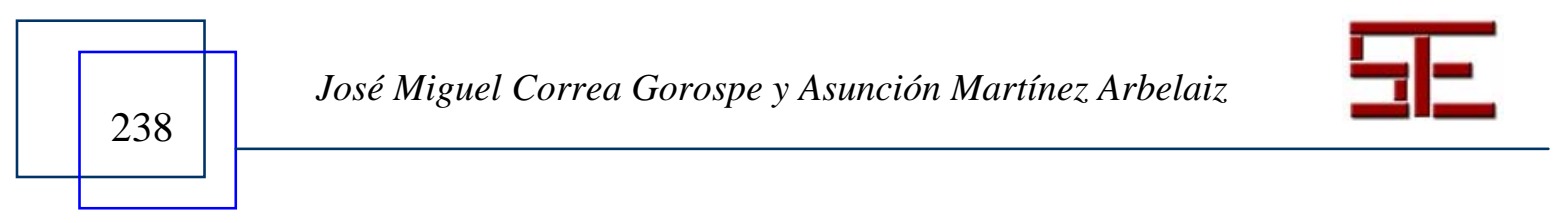




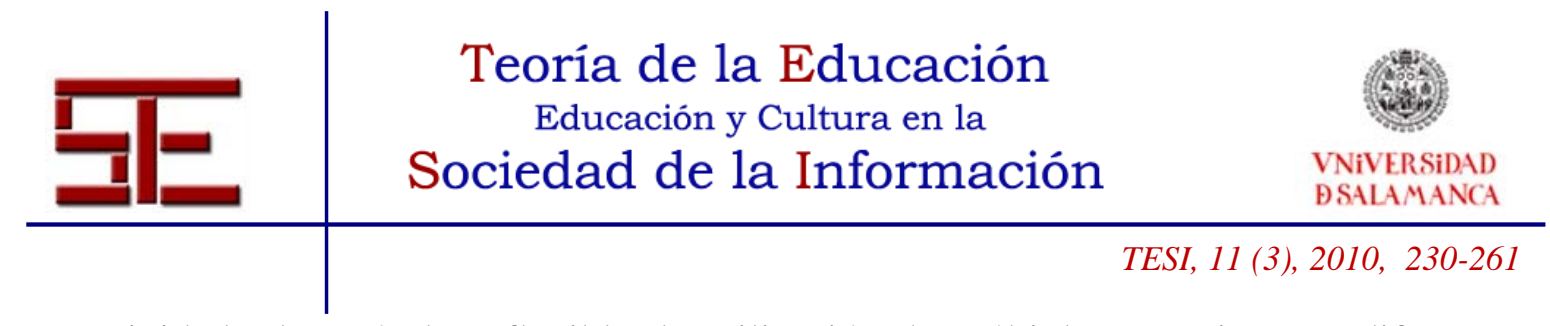

creatividad, el currículum flexible, la utilización de múltiples espacios con diferentes fuentes de recursos, con tareas significativas y complejas, reales y múltiples evidencias de evaluación.

\section{4.- AMARA BERRI}

Amara Berri (www.amaraberri.org) es una escuela pública de San Sebastián con tres sedes de Educación Infantil y tres de Educación Primaria distribuidas por esta ciudad. En total, el centro escolar cuenta con 1.300 alumnos. Asimismo, cuenta con un claustro de 100 profesores.

Se trata éste de un centro escolar con un sistema pedagógico propio, con una fuerte identidad e influencia en muchos otros centros de la Comunidad Autónoma Vasca. La información más extendida del sistema Amara Berri suele estar relacionada con los programas de ciclo, una alternativa a los agrupamientos tradicionales por cursos. Cada ciclo está formado por alumnado de dos niveles diferentes. No hay libros de texto pero sí una biblioteca, no se habla de asignaturas sino de contextos de aprendizaje y de departamentos, no se hace referencia a trabajos escolares sino a actividades-juego. Son habituales las expresiones como "métodos de trabajo", "el para-qué" de todas y cada una de las actividades, la mediateca, las exposiciones de los temas, la organización del alumnado-asambleas, la Txiki Web, la radio, la prensa y, por supuesto, los informativos de la televisión. Amara Berri es más que una buena escuela pública de San Sebastián. Ha sabido convertirse en un referente en la innovación educativa y en los últimos treinta años ha promovido una red de centros Amara Berri. Actualmente esta red cuenta con 20 centros distribuidos por la Comunidad Autónoma Vasca.

Diferentes publicaciones han ido recogiendo la evolución y práctica pedagógica de esta metodología pedagógica. Un texto reciente (Anaut, 2004) recoge una muy buena definición del sistema Amara Berri.

4.1.- Objetivos de la investigación relacionados con la observación de la práctica en el centro Amara Berri

Parte de la investigación sobre políticas educativas TIC en el País Vasco que en la actualidad nos encontramos desarrollando es la identificación de centros escolares que desarrollan buenas prácticas TIC. Dentro de las tareas de esta investigación hemos realizado entrevistas a profesores y equipos directivos y en concreto en este centro observación de la práctica escolar. Uno de los autores de este artículo realizó una observación directa de la práctica en Amara Berri a lo largo de tres meses. Su intención era comprender:

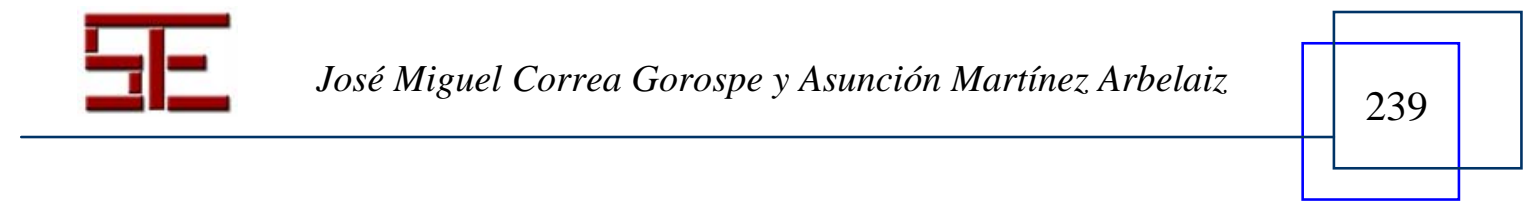




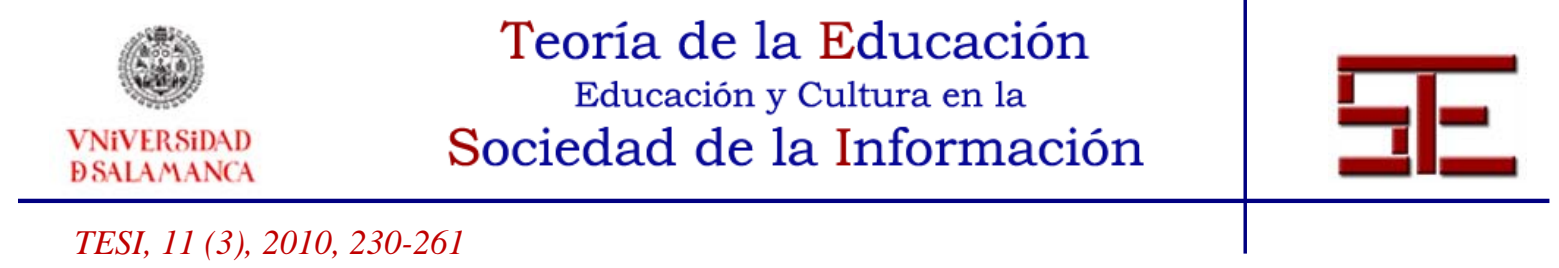

- La organización y estructura espacial y temporal del Departamento de Medios de Comunicación y la interrelación con otros talleres y departamentos de la organización del sistema Amara Berri.

- Los materiales y actividades que se utilizan y criterios para su selección.

- El papel de los alumnos en los diferentes talleres.

- El papel del profesor en su faceta organizadora, orientadora, técnica y pedagógica. En concreto, la interacción con el alumnado, la gestión de los diferentes talleres, el método de trabajo y las estrategias para conseguir los objetivos de las diferentes tareas.

- La cultura del centro con respecto a la finalidad y protagonismo que las tecnologías tienen en su sistema pedagógico.

\section{2.- El Departamento de Medios de Comunicación (Hedabideak) del Colegio Amara} Berri.

En el Colegio Amara Berri, no sólo hay ordenadores en las aulas para las diferentes actividades, también cuenta con un Departamento de Medios de Comunicación, el cual constituye un núcleo fundamental en el sistema pedagógico de Amara Berri. Éste es un aula del centro distribuida en diferentes talleres o rincones de unos treinta metros cuadrados, donde encontramos el estudio de televisión ABT (Amara Berriko Telebista/La televisión de Amara Berri), la cabina de la radio de ABI (Amara Berriko Irratia/La radio de Amara Berri), el taller de la edición de la revista del centro impresa en papel, que se llama ABE (Amara Berriko Egunkaria/El periódico de Amara Berri), el espacio de edición de la web de los alumnos que es conocido como la Txikiweb del Colegio Amara Berri, el taller de la edición de vídeo y un espacio que hace de estanterías de almacenaje y gestión de los trabajos de los alumnos para su publicación en la revista o en la web.

Este Departamento de Medios de Comunicación nos parece especialmente interesante por las actividades que ahí se llevan a cabo, así como por su relación con el resto de las actividades escolares que los alumnos desarrollan en otros departamentos diariamente. Esta interconexión de espacios y actividades marca la relevancia de lo que producen con nuevas tecnologías.

Los principales protagonistas del Departamento de Medios de Comunicación son los alumnos de tercer ciclo. En ellos recae la actividad que se desarrolla en los talleres de Televisión, Prensa y Web.

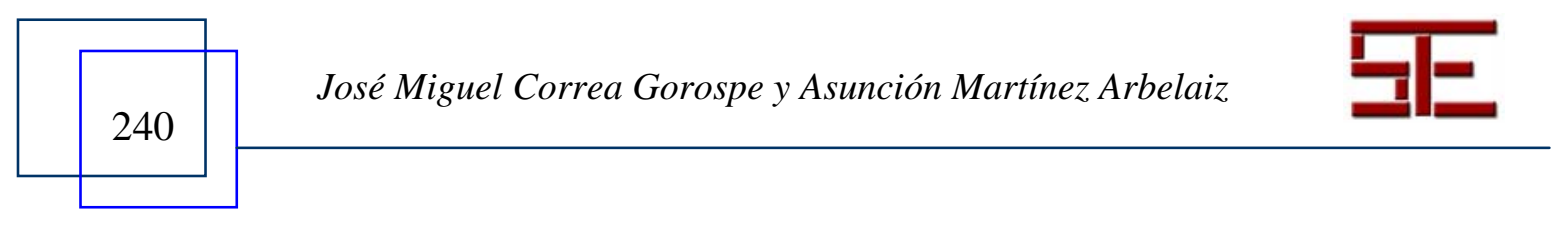




\begin{tabular}{|c|c|c|c|}
\hline 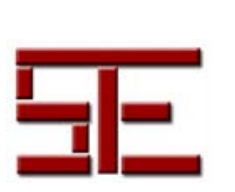 & \multicolumn{2}{|c|}{$\begin{array}{c}\text { Teoría de la Educación } \\
\text { Educación y Cultura en la } \\
\text { Sociedad de la Información }\end{array}$} & $\begin{array}{c}\text { Cing } \\
\text { VNiVERSiDAD } \\
\text { BSALAMANCA }\end{array}$ \\
\hline & \multicolumn{3}{|c|}{ TESI, 11 (3), 2010, 230-261 } \\
\hline $\begin{array}{l}\text { Medio de } \\
\text { comunicación }\end{array}$ & Actividad & Software & Hardware \\
\hline WEB & $\begin{array}{l}\text { Edición de la Txiki-Web del centro. Incluye: } \\
\text { menú de navegación con textos, imágenes de } \\
\text { trabajos de alumnos digitalizados, vídeos } \\
\text { grabados en el taller de televisión o audios } \\
\text { (podcast) grabados en la radio. A partir de los } \\
\text { trabajos que se realizan en diferentes } \\
\text { Departamentos del centro y otros productos } \\
\text { desarrollados en el propio Departamento de } \\
\text { Medios de Comunicación. Digitalización de } \\
\text { cuentos. Cuenta con una implicación de } 4 \\
\text { alumnos de tercer ciclo cada día para las } \\
\text { tareas de edición y montaje de la Txikiweb. }\end{array}$ & I Web de Apple & $\begin{array}{l}2 \text { ordenadores } \\
\text { Mac y } 2 \text { escáneres } \\
\text { I Pod }\end{array}$ \\
\hline REVISTA & $\begin{array}{l}\text { Edición diaria de la Revista ABE de una } \\
\text { extensión de } 6 \text { a } 8 \text { páginas. Con una parte } \\
\text { elaborada por el equipo de redacción y otra } \\
\text { donde se recogen trabajos de los alumnos de } \\
\text { todos los ciclos del centro. Se redactan en } \\
\text { tres lenguas (castellano, euskara e inglés), } \\
\text { según las actividades que se editen. } 4 \\
\text { alumnos de tercer ciclo se ocupan de realizar } \\
\text { la revista. }\end{array}$ & I Pages de Apple & $\begin{array}{l}2 \text { ordenadores } \\
\text { Mac OX } \\
\text { Impresora } \\
\text { Escáner } \\
\text { Cámara de fotos }\end{array}$ \\
\hline TELEVISIÓN & $\begin{array}{l}4 \text { alumnos del tercer ciclo se ocupan del } \\
\text { trabajo del Estudio de Televisión de ABT/La } \\
\text { Televisión de Amara Berri/Amara Berriko } \\
\text { Telebista. Cuenta con dos espacios: el propio } \\
\text { estudio de grabación y el taller de edición de } \\
\text { video. Se graban diferentes actividades } \\
\text { curriculares que luego se editan. Hay dos } \\
\text { sesiones colectivas que se emiten a todos los } \\
\text { alumnos. }\end{array}$ & $\begin{array}{l}\text { I Movie de } \\
\text { Apple }\end{array}$ & $\begin{array}{l}2 \text { ordenadores } \\
\text { Mac } \\
\text { Vídeo grabadora } \\
\text { Magnetoscopio, } \\
\text { micrófonos }\end{array}$ \\
\hline RADIO & $\begin{array}{l}\text { ABI, Radio Amara Berri/Amara Berriko } \\
\text { Irratia. Cuenta con la colaboración de } 2 \\
\text { alumnos de segundo ciclo. Se emite en la } \\
\text { frecuencia de } 107.2 \text { y se oye en el barrio de la } \\
\text { Escuela durante la jornada escolar. Está } \\
\text { relacionada con las actividades curriculares. }\end{array}$ & & $\begin{array}{l}\text { Micrófonos } \\
\text { Pletina }\end{array}$ \\
\hline
\end{tabular}

Tabla 1: Resumen de tecnologías del Departamento de Medios de comunicación

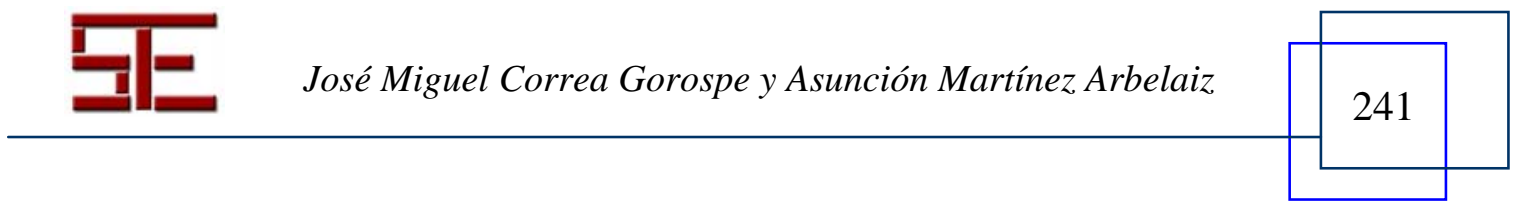




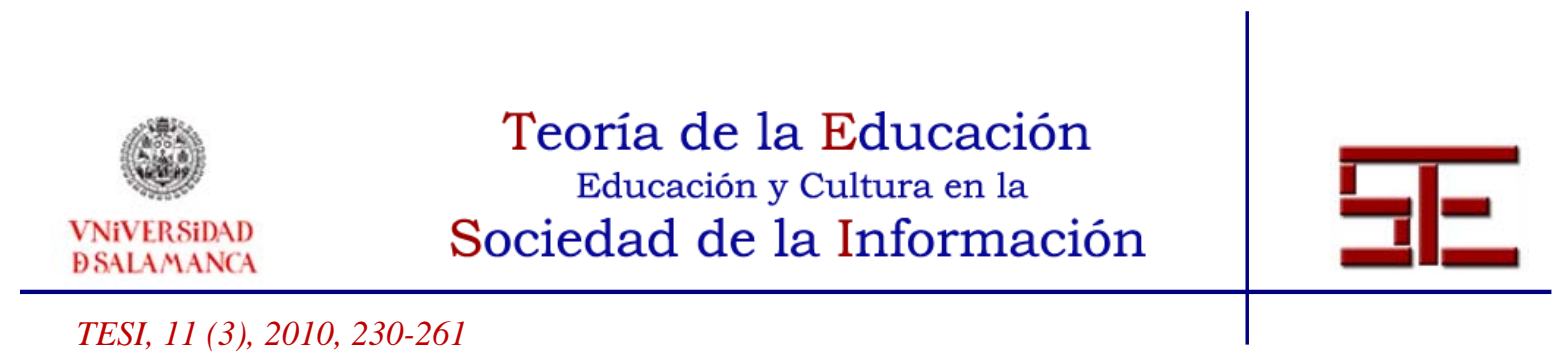

4.3.- $W e b^{2}$

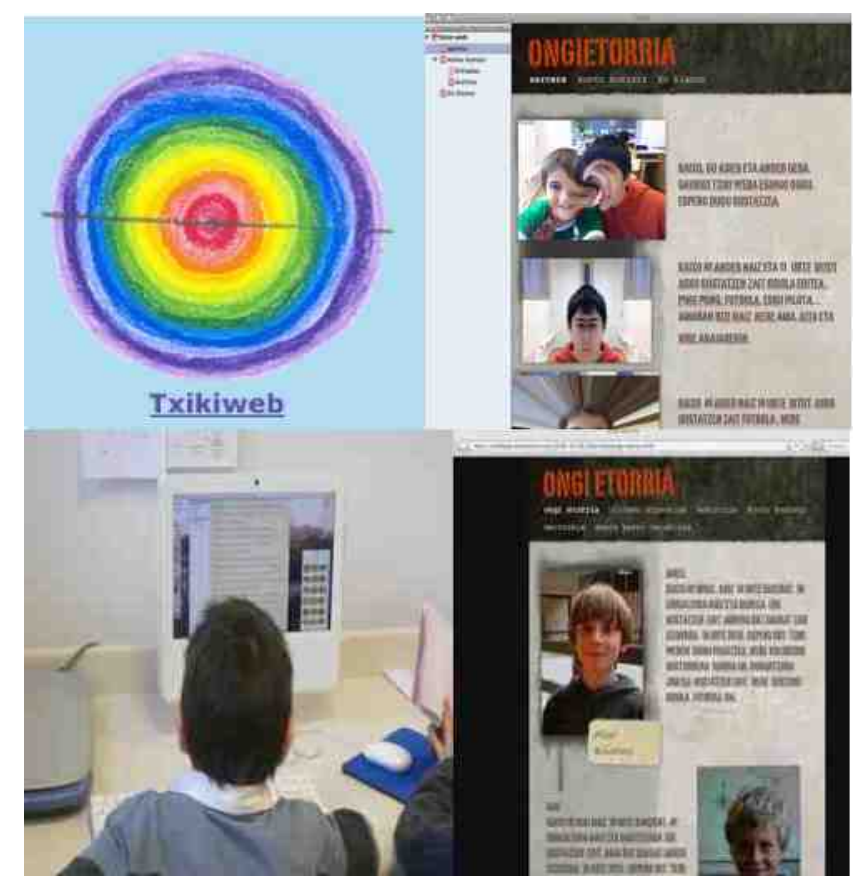

Imagen 1: Txiki-Web

La Txiki-Web es una de las actividades que se realizan en el departamento de Medios de Comunicación del Colegio Amara Berri. Se puede visualizar los trabajos en (http://amaraberri.org/topics/abvirtual/txikiweb/). Trabajan en este taller diariamente dos parejas de alumnos del tercer ciclo, de quinto y sexto curso. En la Imagen 1 podemos ver el logotipo identificador de la Txiki-Web y dos momentos del proceso de elaboración de la página principal de la web y una escena del proceso colaborativo de trabajo. Los responsables van completando los diferentes apartados de la Txiki-Web y, de esta manera, preparan la página principal con las fotos que sacan ellos mismos con el programa Photo Booth y con la cámara incorporada de los ordenadores de sobremesa. Así mismo trabajan sus textos personales de presentación o los demás contenidos con los que editan su web. En la Imagen 1 puede verse el logotipo de la Txiki-Web, así como diferentes fases de este proceso de creación.

\footnotetext{
${ }^{2}$ Se puede consultar un vídeo titulado "La Txiki Web del Colegio Amara Berri” donde se recoge el proceso de edición y publicación de la Txiki Web. Ver Correa Gorospe, J.M. (2009). La Txiki Web del Colegio Amara Berri. Disponible en: http://www.archive.org/details/AmaraBerriTxikiWeb.
}

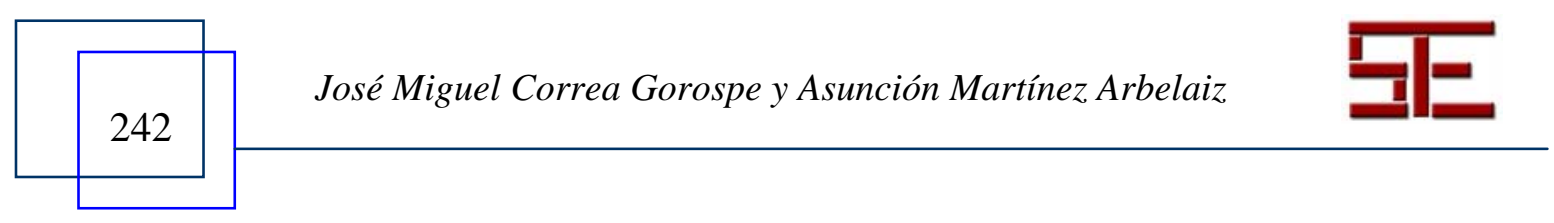




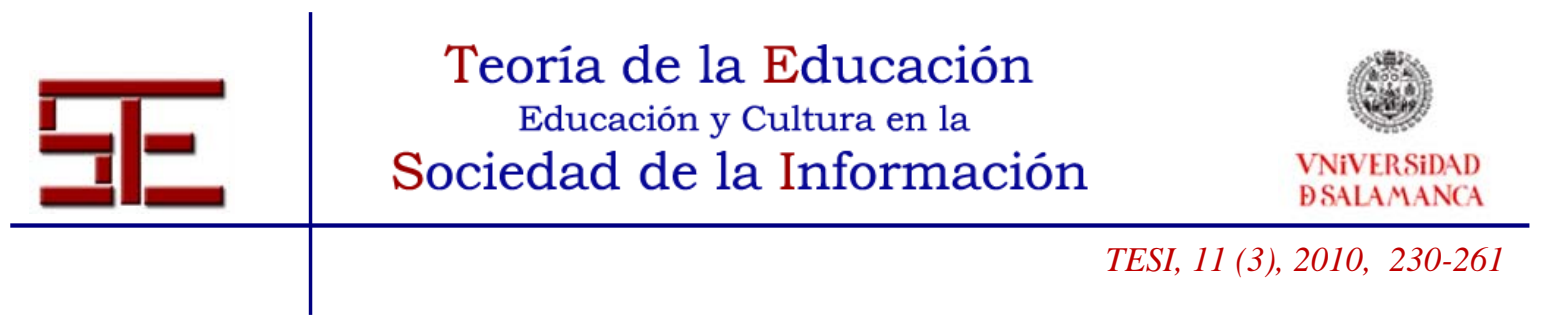

Normalmente la web cuenta con una estructura flexible, para dar cabida a las diferentes producciones. Una de las secciones fijas suele ser la presentación titulada Ongietorri/Bienvenida, donde se presentan los autores responsables de la edición, con sus nombres y fotografías y nos ofrecen unas palabras de bienvenida. Los alumnos utilizan en la edición de la web el euskara o el castellano. En otras secciones tituladas "Galería de artistas pequeños", la cual recoge los dibujos escaneados de los alumnos de Educación Infantil, "Películas de la TV de Amara Berri", "Fotografías" o "Kontu Kontari" (Contar Cuentos), tratan de recoger la actividad del centro, mostrando los trabajos que se realizan en otros Departamentos como Lenguas. Digitalizan escaneando las imágenes de los cuentos que han dibujado y transcriben los textos que han escrito los alumnos de primer ciclo. Graban con el podcast la emisión del cuento por la radio. Todo ello, así como diferentes grabaciones de lo que han realizado en el taller de la televisión (entrevistas, dramatizaciones, playbacks) lo cuelgan en la web.

Una herramienta fundamental para la planificación es la programación del taller. En la hoja de programación del taller se recoge un calendario donde aparecen los nombres de las alumnas que durante el trimestre pasarán por el taller y serán las encargadas de la edición. Además, para el trabajo diario de edición de la Txiki-Web, cuentan con la ficha Webmaster donde aparece la fecha, el nombre de los responsables, los contenidos que se editarán en cada uno de los apartados y los nombres del grupo de trabajo responsable. También en esta ficha hay un apartado de evaluación de cómo ha ido el trabajo.

Los contenidos de la Txiki-Web recogen y reflejan fundamentalmente trabajos que realizan los alumnos en los diferentes departamentos y productos elaborados en el propio Departamento de Medios de Comunicación. La web maneja para su edición las películas que se graban y editan en el taller de televisión, de diferente contenido desde conciertos "académicos" de música de los alumnos hasta grabaciones de dramatizaciones, o magazines variados que se han realizado en el estudio de televisión. Los podcast recogen las grabaciones de audio que se graban en la radio, cuando los alumnos, por ejemplo, leen sus cuentos. También entre los contenidos podemos ver imágenes de otros trabajos escaneados o fotografiados diversos a los que se quiere dar relevancia. Toda esta actividad se puede consultar a través de la web del centro.

Aunque los autores de la edición de la web son los alumnos de tercer ciclo, este taller del Departamento de Medios de Comunicación promueve la participación de todos los alumnos del centro, gracias a la publicación de diferentes trabajos del alumnado de todos los niveles y a la coherencia curricular de las actividades. Las fotos de los participantes y de los responsables de los trabajos favorecen una estrategia que permite compartir y dar relevancia a todos los alumnos de los diferentes ciclos.

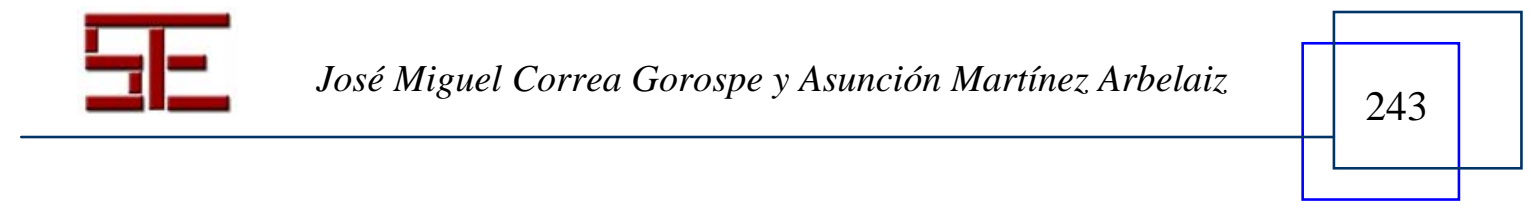




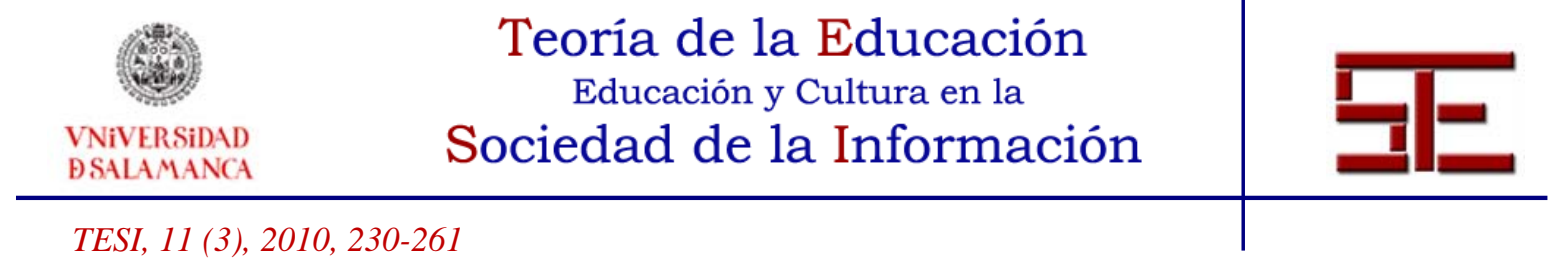

Los alumnos que editan la web reciben un diploma donde se reconoce su trabajo y autoría y donde aparece la dirección exacta de Internet donde se puede visualizar. De manera que, cuando van a casa, llevan la dirección exacta que sirve para dar a conocer a la familia el trabajo que han realizado. Esta web permanecerá durante el curso albergada en el sitio web del colegio y podrá ser consultada.

La actividad que se realiza en la Tiki-Web y el trabajo desarrollado por los alumnos en el Departamento de Medios de Comunicación se evalúa conjuntamente y se repasa tanto la calidad como el proceso de producción.

El protagonismo en el taller de la Txiki-Web recae en los alumnos y el papel del profesor encargado de este Departamento, desempeña un rol de guía o dinamizador de las actividades. Él responde puntualmente a las dificultades tecnológicas que puedan surgir o sugiere algún matiz en las ediciones además de dialogar y revisar las producciones de los editores. Los alumnos trabajan por parejas de forma cooperativa, al estar agrupados los de quinto curso con los de sexto. Los alumnos mayores ya conocen la experiencia al haber estado el año anterior trabajando en este Departamento, lo que facilita el funcionamiento y les permite asesorar a su compañero para quien la experiencia es novedosa.

Las actividades que se realizan en cada uno de los talleres están semi-estructuradas, con ciertas secciones fijas que se han de rellenar de contenido. Hay un guión mínimo pero permite la flexibilidad suficiente para adaptarse al ritmo escolar y también a su diversidad. Para apoyar el desarrollo de las actividades el alumnado cuenta con información sobre el funcionamiento tecnológico y por supuesto también cuenta con la ayuda del profesor.

Los recursos tecnológicos, en concreto, tanto los ordenadores Mac como el software I Web de Apple, permiten editar la Txiki-Web con imágenes, audio y vídeos con facilidad.

Bidaia Zoragarria (El Viaje Maravilloso) puede ser un buen ejemplo de cómo una actividad que se inicia en el aula de lengua de primer ciclo, posteriormente se trabaja en la radio y se publica en la red. Los alumnos trabajan el desarrollo de la lengua en el taller de Hizkuntza (Lengua), realizando entre otras actividades la creación de cuentos. Inventan una narrativa, la ilustran con sus propios dibujos y luego la leen en la radio, donde se emite al barrio. Mientras están emitiendo en abierto para el barrio por la radio, los encargados de la Txiki-Web graban con el podcast y luego editan el archivo con el audio en la web y el cuento escaneado.

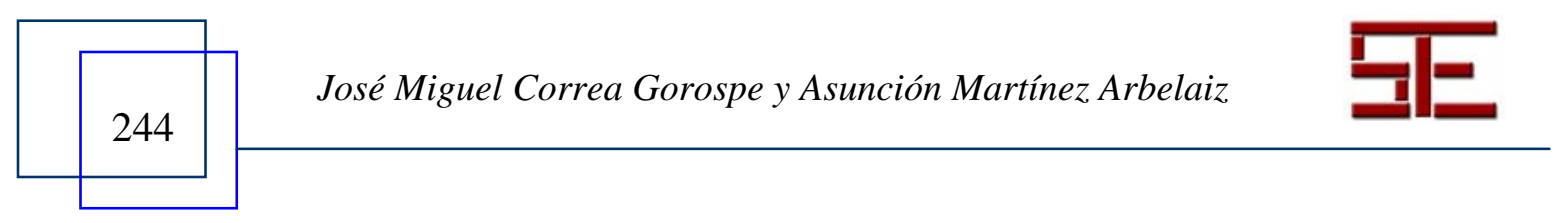




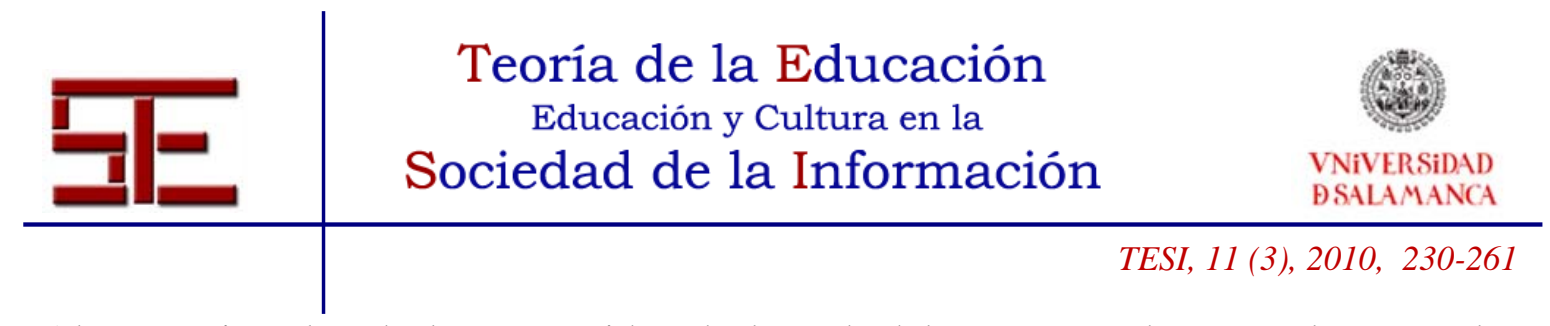

Algunos ejemplos de los contenidos de la web del centro pueden consultarse en las direcciones siguientes:

http://txikiweb.amaraberri.org/2008-11-21/Sitio web /kontu kontari/E922F7B4-58754CE3-B372-D132C9EFE0BC.html y el cuento escaneado ver en:

http://txikiweb.amaraberri.org/2008-11-21/Sitio web /Bidaia Zoragarria.html

Estos cuentos, vídeos, dibujos o producciones plásticas no sólo son evidencias de buenas prácticas sino también un reflejo de la coherencia del sistema Amara Berri, por la manera de implicar las diferentes áreas curriculares y departamentos del centro en la base de la actividad tecnológica, dándole una orientación marcadamente social y participativa. No sólo dotamos de contenidos creativos nuestra web sino que la utilizamos para darnos a conocer y compartir comunitariamente nuestros trabajos.

La Txiki-Web (http://amaraberri.org/topics/abvirtual/txikiweb/) está llena de ejemplos del trabajo que realizan en el Departamento de Medios de Comunicación. A continuación describimos una escena de las que cotidianamente acontecen en el taller de la web:

“Asier y Niko, están editando la página web. Están haciendo la portada. Se sacan una foto con el programa Photo Booth. Cuando han editado la foto se entretienen explorando todas las posibilidades del programa. Alargan la foto $y$ luego la ensanchan. De nuevo la deforman y se ríen. Descubren una variedad de posibilidades. Después empiezan a hacer la tarea continuando el montaje de la página web. Insertan sus fotos y escriben el texto de bienvenida y prueban diferentes tipos de letras y colores. Amando se acerca y les orienta en los pasos para subir a la web el cuento y cómo insertar la foto de Alisha, alumna de segundo ciclo, que han grabado por la mañana con el podcast en el estudio de radio. Después, continúan digitalizando con el escáner los dibujos de los alumnos de educación infantil."

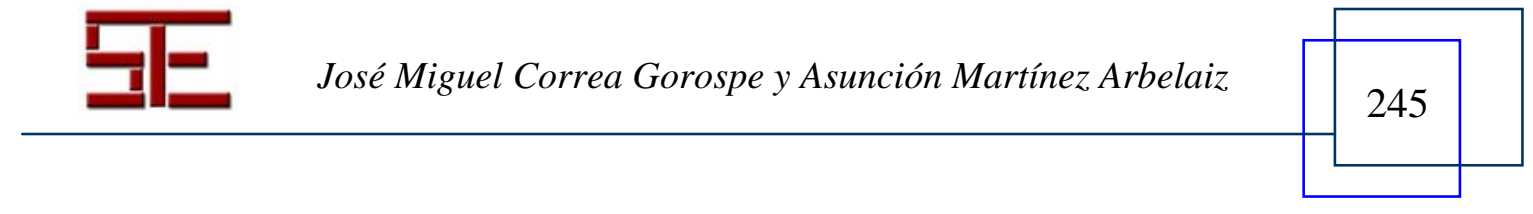




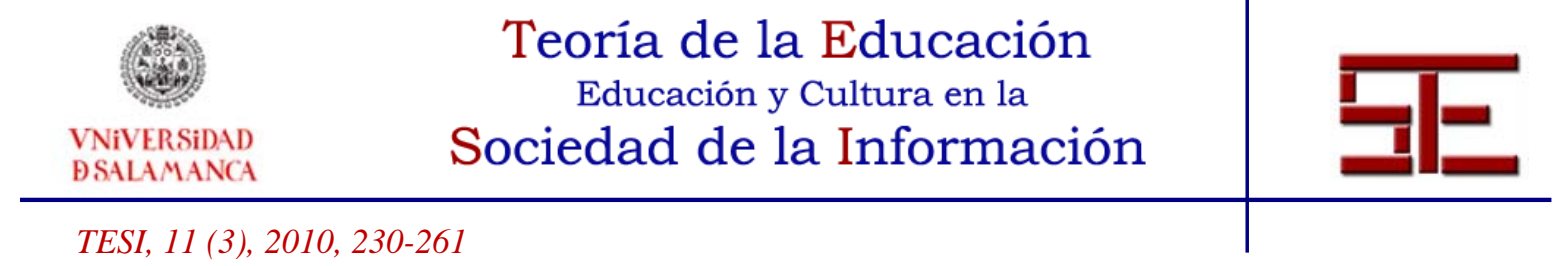

\section{4.- Periódico ${ }^{3}$}

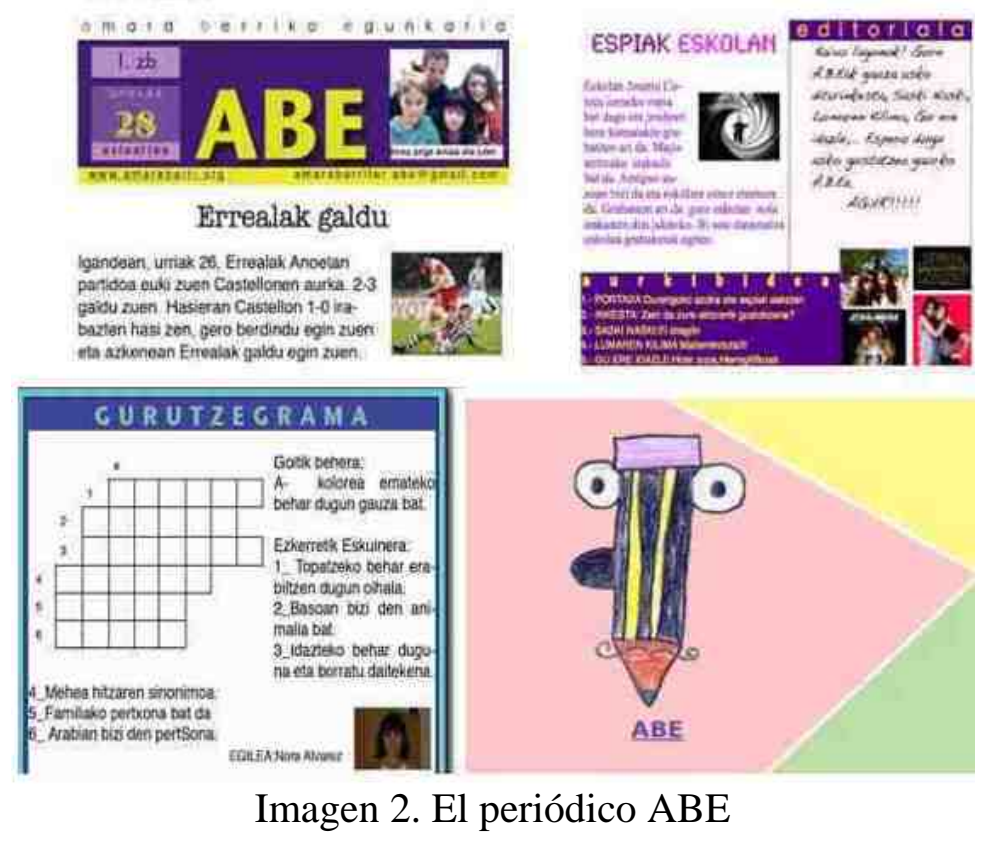

El periódico que se publica diariamente es el ABE, Amara Berriko Aldizkaria, de unas 6-8 hojas. Hay una versión digital accesible desde la página web del centro escolar. En la Imagen 2, podemos ver la parte superior e inferior de la revista $\mathrm{ABE}$, en la parte inferior el logotipo de la emblemática revista y un ejemplo de crucigrama. La dirección donde se encuentra colgada la revista es: http://amaraberri.org/topics/abvirtual/revisonline/. Cada día cuatro alumnos de tercer ciclo se ocupan con dos ordenadores de seleccionar y editar la revista. Dos de estos cuatro alumnos que se ocupan de editar la revista han trabajado el día anterior y dos son nuevos, de manera que se renueva el equipo de trabajo.

Se empieza con una reunión de planificación de contenidos de la revista, la cual cuenta con secciones fijas donde se recoge la actividad escolar del centro. El índice enumera las siguientes secciones:

- Portada: es la primera hoja y en ella aparece el título de la revista, la fecha de edición, el editorial y el índice. La segunda hoja es una Entrevista sobre una variedad de temas,

\footnotetext{
${ }^{3}$ Se puede consultar un vídeo titulado "El periódico Amara Berri”, donde se recoge el proceso de edición de este periódico. Ver Correa Gorospe, J.M. (2009). El periodico de Amara Berri. Disponible en http://ia331418.us.archive.org/0/items/AbeAmaraBerrikoEgunkaria/PrensaCastellano.m4v.
}

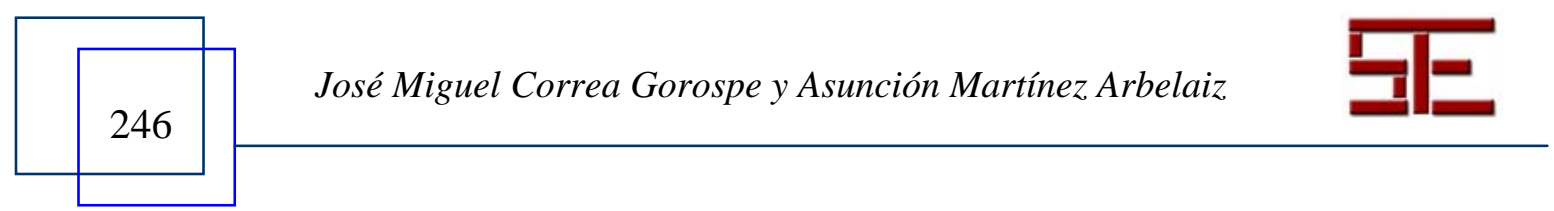




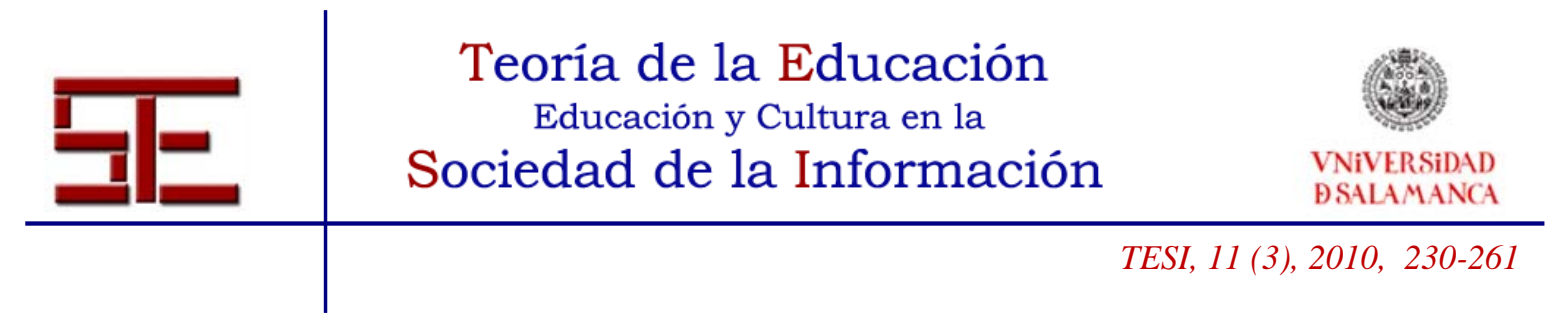

por ejemplo: “¿Con quién irías de vacaciones más a gusto...?”; y también aparecen noticias de actualidad de la Escuela, como, por ejemplo: "El equipo de fútbol de Amara Berri ha jugado este domingo..." o "Han venido unos alumnos de la Escuela de Magisterio de Vitoria-Gasteiz". La primera y segunda hoja de la revista la hacen los alumnos editores.

- Saski Naski (Cajón de Sastre), la cual contiene poesías, canciones, cuentos y se publica con escritos de alumnos del primer ciclo.

- Lumaren Kilima (Cosquillas literarias) cuenta con narraciones cortas o descripciones de cosas, como por ejemplo un estuche de guardar lápices. En esta sección se suelen publicar trabajos de los alumnos del tercer ciclo.

- Gu ere Idazle (Nosotros también escritores). En esta sección se publican actividades de entretenimiento como sopa de letras o crucigramas. Son trabajos realizados por alumnos de segundo ciclo.

Los contenidos de la revista también se mandan desde otros departamentos por e-mail o se depositan en el aula del Departamento de Medios de Comunicación en unas estanterías con etiquetas dispuestas para depositar las aportaciones de los alumnos de otros departamentos. Los alumnos a lo largo del día vienen al aula y dejan los trabajos. Las noticias de la revista se escriben en castellano, euskara o inglés. Para la realización del trabajo los alumnos cuentan con una cámara de fotos, una impresora en color y recurren a Internet para buscar imágenes. Editan con software de Apple, concretamente con Pages.

Hay una ficha de redactores, que les sirve para planificar el trabajo del día, aparece la fecha, los nombres de los redactores y el número de la revista a la que corresponde. Se detallan los contenidos de cada una de las hojas de la revista, especificando los nombres de los autores de los trabajos y de los pasatiempos que se van a publicar. En la ficha de redactores aparecen unas preguntas para la valoración del trabajo. Estas preguntas, las cuales sirven para orientar la autoevaluación, son de este tipo: ¿Ha sido bueno el ambiente de trabajo?, ¿Habéis repartido bien el trabajo?, ¿Había apartados para rellenar?, ¿Habéis elegido fotos adecuadas para meter en los artículos?, etc.

A continuación relatamos una escena del taller de la revista, recogida del cuaderno de campo de la investigación:

"Hoy Irati, alumna del tercer ciclo, está editando la revista. Transcribe un texto en inglés sobre Xabi Alonso, jugador del Liverpool y antes jugador de la Real Sociedad. En el texto se recoge la vida deportiva del jugador, sus gustos y aficiones. Quiere poner una foto del jugador en el artículo que está transcribiendo. Ahora está buscando en Internet con el buscador de imágenes de Google. Realiza la búsqueda y aparecen muchas imágenes. Ella ha encontrado una fotografía interesante “esa, esa...” y la ha copiado. Utilizando

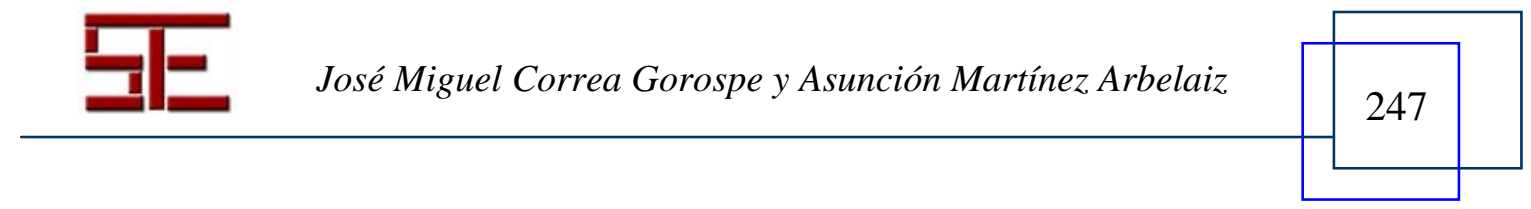




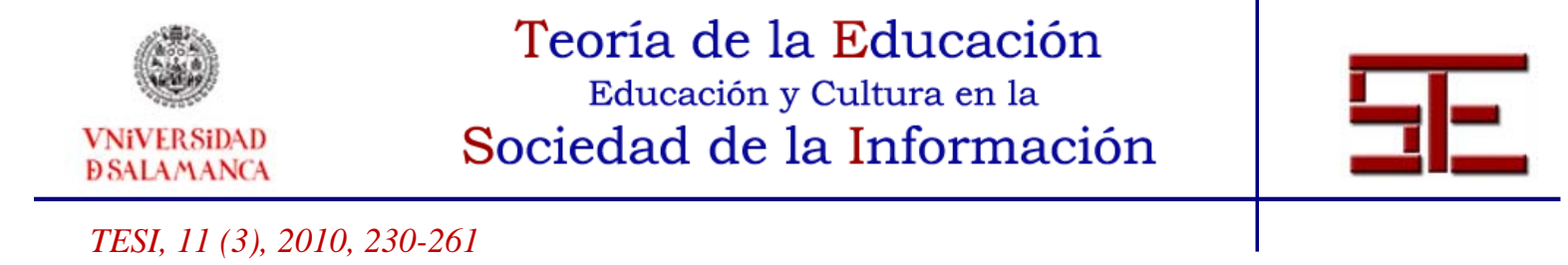

el lado derecho del ratón selecciona "Guardar imagen como" y la deposita en el escritorio del ordenador. A su lado su compañera le explica cómo insertar en el texto esa fotografía..."

\section{5.- Televisión ${ }^{4}$}

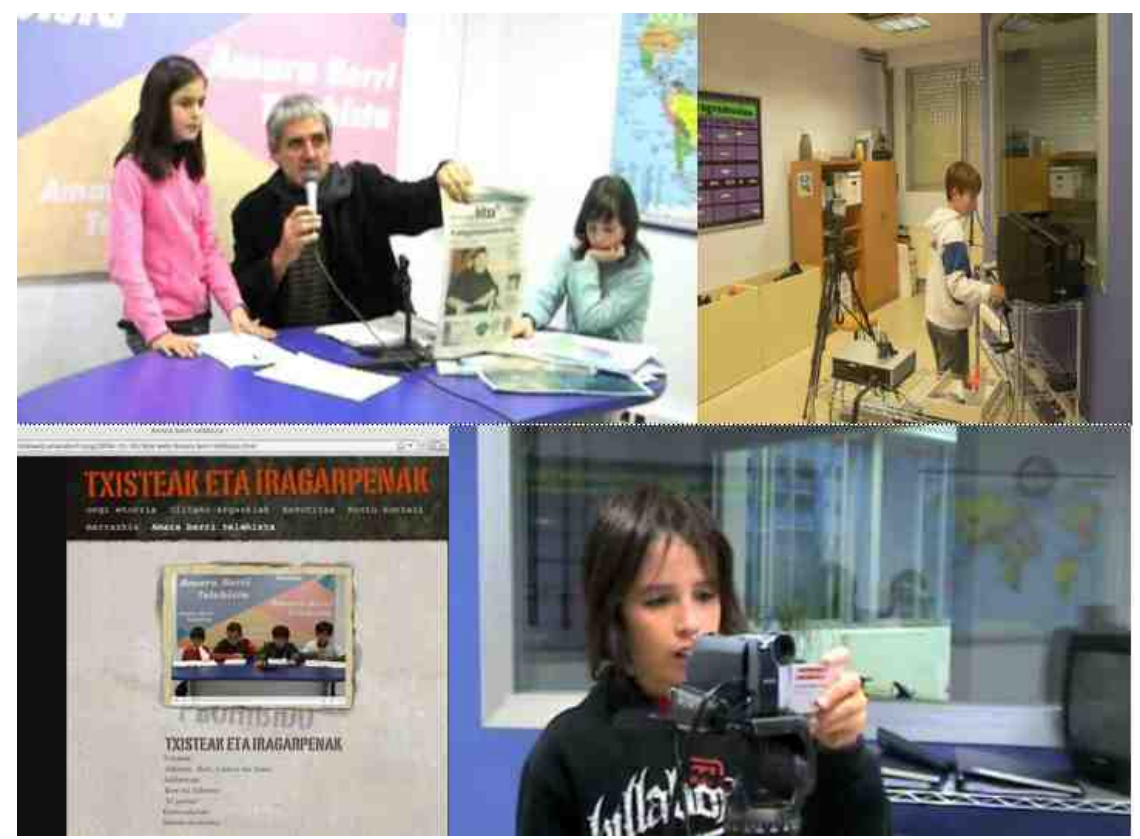

Imagen 3. La televisión de Amara Berri

Este taller tiene dos espacios bien definidos, por un lado, el plató de televisión y por otro el espacio de edición de vídeo. El espacio del plató de televisión cuenta con un panel donde aparece el nombre del canal de televisión: Amara Berri Telebista. Aquí se realizan las grabaciones de programas. Cuenta con una infraestructura tecnológica básica donde podemos encontrar, entre otros recursos, la cámara de vídeo, trípode, micros, monitor, magnetoscopio para proyectar vídeos analógicos, etc. También cuenta con diferentes ropajes, telas, sombreros que se utilizan para disfrazarse en las dramatizaciones que graban los alumnos. La actividad del taller de televisión es muy variada, como se puede observar en la Imagen 3, donde podemos ver a los alumnos en las diferentes fases de grabación y edición. También observamos la escena del

${ }^{4}$ Se puede consultar un vídeo titulado Televisión Amara Berri, donde se recoge el proceso de edición y producción. Ver Correa Gorospe, J.M. (2009). Televisión Amara Berri. Disponible en: http://www.archive.org/details/LaTelevisionAmaraBerri.

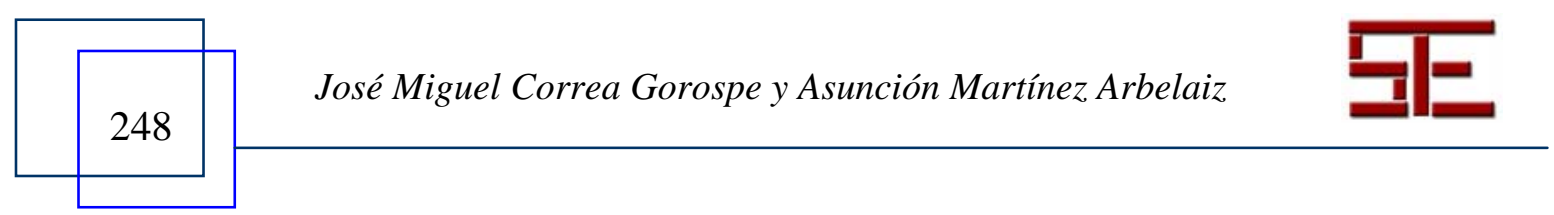




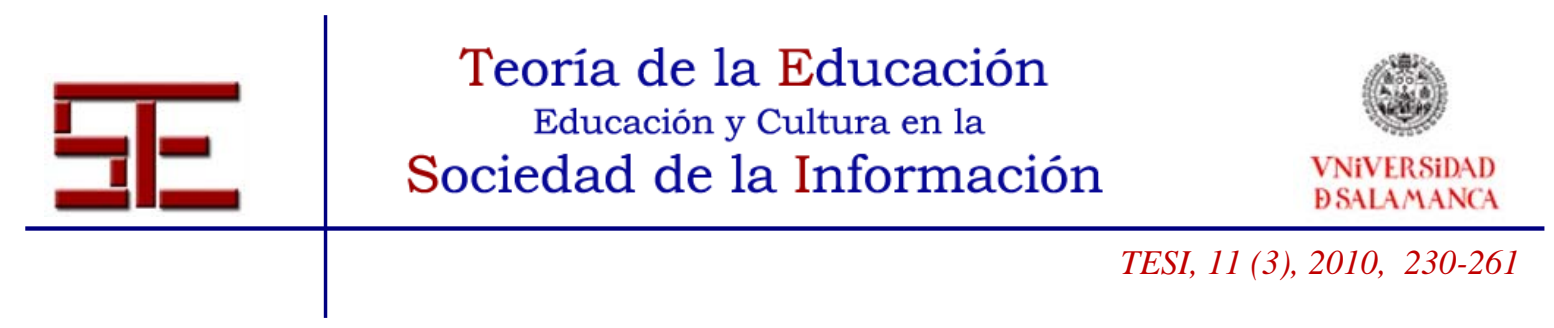

informativo que se emite para el centro y la Txiki-Web donde aparecen los programas que se han grabado y posteriormente editados.

Fundamentalmente, hay un tipo de emisión fija de una hora los jueves por la mañana dirigida por un profesor y una actividad permanente de grabaciones de actividades que los alumnos han preparado en otros departamentos y graban para, tras su edición, publicarla en la Txiki-Web. Todo un amplio repertorio de actividades escolares se convierten en contenido del taller de televisión. Como complemento a las tareas de grabación de los programas de televisión que se realizan en el plató, los alumnos trabajan en el espacio de edición de vídeo, donde cuentan con un ordenador para editar las grabaciones que han realizado en el estudio o fuera de él. En este espacio cuentan con los recursos para digitalizar las grabaciones realizadas y editarlas. En concreto, utilizan el programa I Movie de Apple. En este espacio del taller, además de digitalizar las grabaciones las diseñan cortando y pegando y poniéndoles música, títulos, transiciones y, finalmente, editando los vídeos.

Para organizar el trabajo de estos dos espacios (grabación y edición) del taller de televisión cuentan, como en el resto de los talleres, con unas fichas informativas para el registro de las actividades de los cámaras donde aparece la fecha y el nombre de los responsables de la actividad en el estudio de grabación y el horario de grabación de programas. Esta ficha les ayuda a planificar las actividades. Otro de los recursos fundamentales de este taller es la información del funcionamiento tecnológico. Tanto en el espacio de grabación como en el de edición, cuentan con una hoja plastificada, donde se les informa por escrito del uso y funciones de los recursos tecnológicos que manejan. Esta información les ayuda a trabajar, aunque siempre uno de los dos alumnos de tercer ciclo responsables ya ha pasado anteriormente por este taller y conoce su funcionamiento.

Las actividades en el estudio de grabación son muy variadas en cuanto a temática y clima. Existen grabaciones muy lúdicas, donde los participantes se disfrazan, bromean, cantan o dramatizan con mucho margen de libertad y otras actividades más serias de contenido más informativo. Los alumnos responsables se mueven con libertad, juegan e improvisan, trabajan en este taller "como si" realmente fuesen adultos emitiendo en una cadena de televisión. Se prueban a ellos mismos, se autorregulan. Tienen un plan de actividades que realizar y se responsabilizan de ello, pero sin privarse del juego. No suele haber una directa supervisión adulta, aunque puntualmente el coordinador del Departamento colabora con ellos, pero suele estar más centrado en el resto de los talleres. A continuación se puede leer una descripción de una escena del programa semanal que se emite para todas las clases del colegio y otras dos que retratan la actividad de los alumnos trabajando en el espacio de edición:

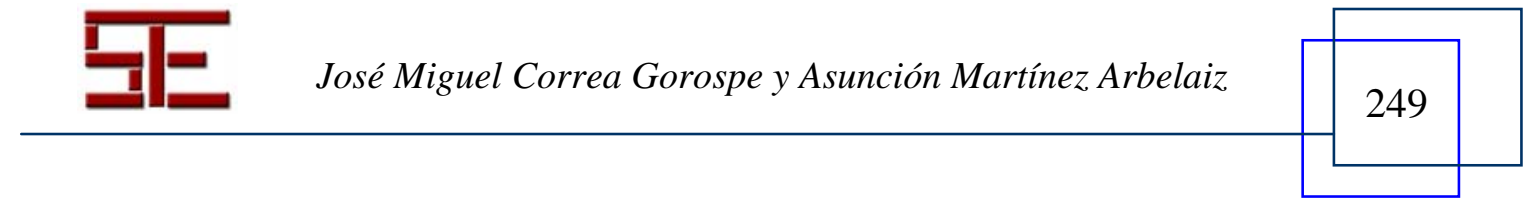




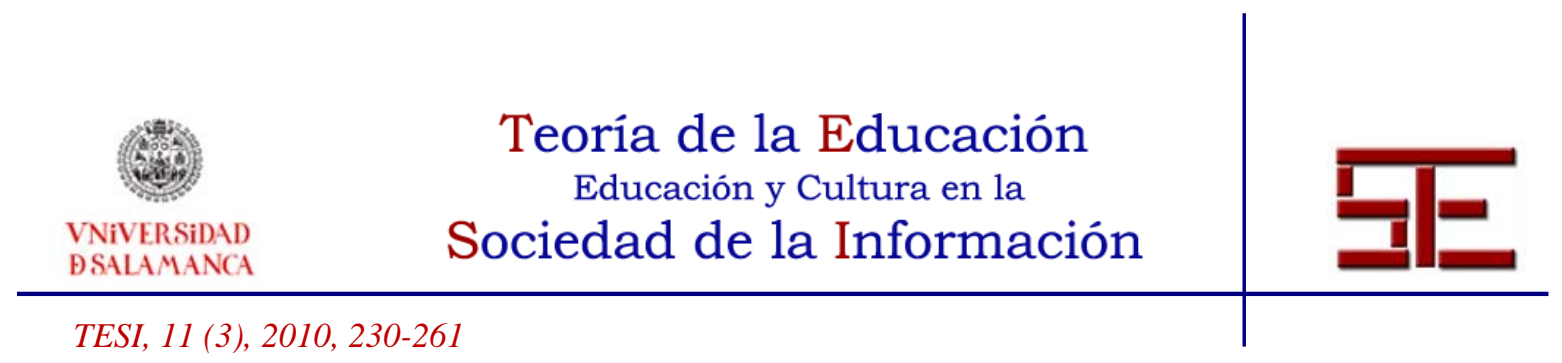

“Es jueves por la mañana, Juales, que tradicionalmente dirige esta sesión, está en el plató de televisión preparando a los diferentes alumnos que intervendrán en el programa de Amara Berriko Telebista (Televisión de Amara Berri). Los alumnos tienen las noticias preparadas. Amando -el coordinador del Departamento de Medios de Comunicación- se está ocupando de los detalles técnicos. Hoy le entrevistará a un alumno de Magisterio que está haciendo las Prácticas estas últimas semanas. Al empezar Juales, que está sentado en la mesa del plató con otros dos alumnos, saluda e informa de la sesión de hoy: hay muchas cosas que contar. Los alumnos empiezan dando la información referente al día de hoy: fecha, tiempo atmosférico, menú del mediodía en el comedor, etc. Acompañando a Jon, que lee la información, está Álvaro, un alumno con dificultades auditivas, que signa la información que se va dando. Las noticias y los informantes se suceden; el paro, despidos, información internacional, la muerte del cantante Mikel Laboa, los deportes...”

"Laura de $6^{\circ}$, ha estado editando esta mañana la grabación que hicieron ayer en el estudio de televisión. En la grabación se le ve con un mapa de EuskalHerria. Ella explica la ubicación de los diferentes territorios y las capitales. Posteriormente se le ve mostrando un mapa del mundo, ella me dice mientras importa al I Movie esta grabación desde la videocámara, que estaban haciendo una grabación informal. Ahora está con David, de $5^{\circ}$, que se acaba de incorporar y no sabe manejar el editor. Ella le está enseñando, le orienta en los diferentes pasos: importación de la videocámara, creación de miniaturas en el escritorio del programa, el volcado y la organización de las diferentes secuencias, la elección de transiciones y la edición de títulos. Amando se sienta con ellos para visionar el trabajo realizado. Les orienta con los títulos del vídeo."

"Esta mañana Alex y Kiara han estado editando diferentes vídeos, entre ellos una grabación del trabajo de una presentación de clase de una alumna sobre "el cocodrilo”. Primero han pasado las imágenes de la videocámara al ordenador, luego han elegido unos fragmentos y han generado miniaturas en el escritorio de I Movie del vídeo que habían grabado en el plató de la televisión. Luego han puesto títulos a los diferentes momentos de la grabación que han seleccionado al principio, medio y final, han elegido transiciones y han puesto música. Para seleccionar la música han accedido al I Tunes y han elegido la música que han considerado más adecuada.”

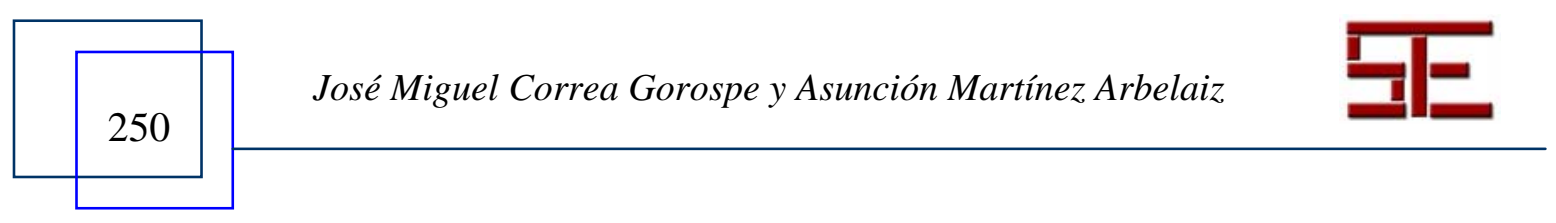




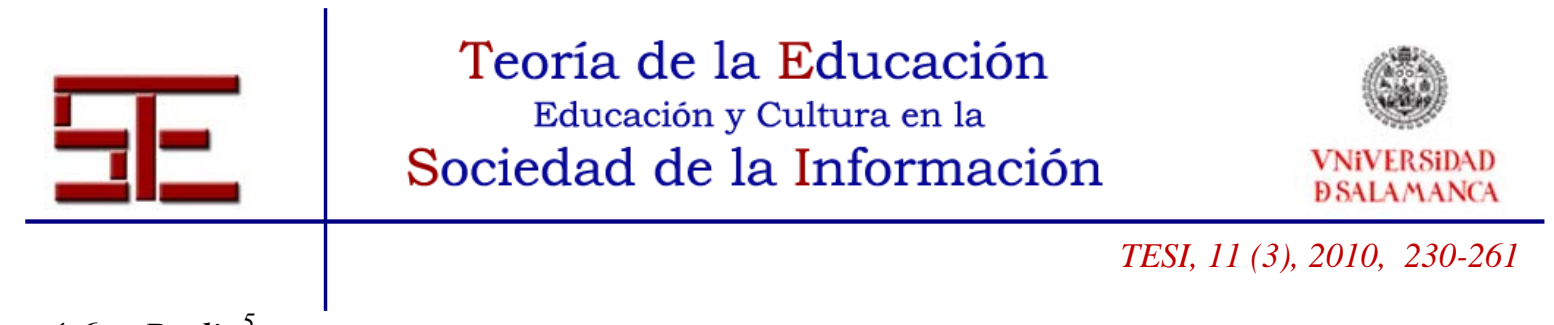

4.6.- Radio $^{5}$

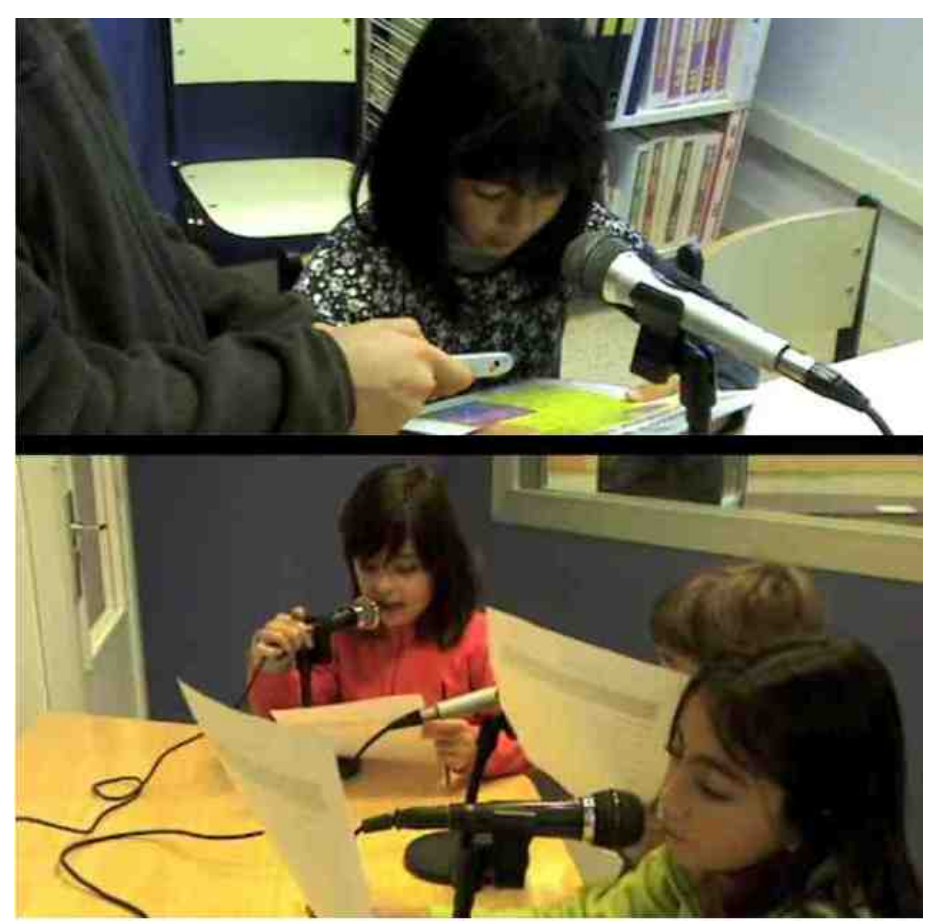

Imagen 4. La radio de Amara Berri

Amara Berri Irratia/Radio Amara Berri, se emite en la frecuencia 107.2 en abierto para todo el barrio de Amara y Centro, donde están enclavadas las sedes de la Escuela. En la Imagen 4 aparece en la parte superior, una escena donde un alumno graba con un podcast a una alumna leyendo un cuento. En la parte inferior alumnos del segundo ciclo grabando un informativo que habían preparado.

En el taller de Radio hay dos espacios: una cabina con los micros para realizar las emisiones en directo y al otro lado, en el espacio común compartido con los talleres de prensa, web y el espacio de edición de vídeo, una zona de control, con la mesa de edición para encender y apagar, manejar el volumen de la música o dar entrada a los micros.

Hay dos tipos de actividades en este taller: a) la organizada y dirigida por los alumnos en abierto para el barrio y b) otra emisión un día a la semana, coordinada por una

\footnotetext{
${ }^{5}$ Se puede consultar un video titulado Radio Amara Berri, donde se recoge escenas de esta experiencia educativa. Ver Correa Gorospe, J.M. (2009). Radio Amara Berri. Disponible en: :http://www.archive.org/details/RadioAmaraBerri
}

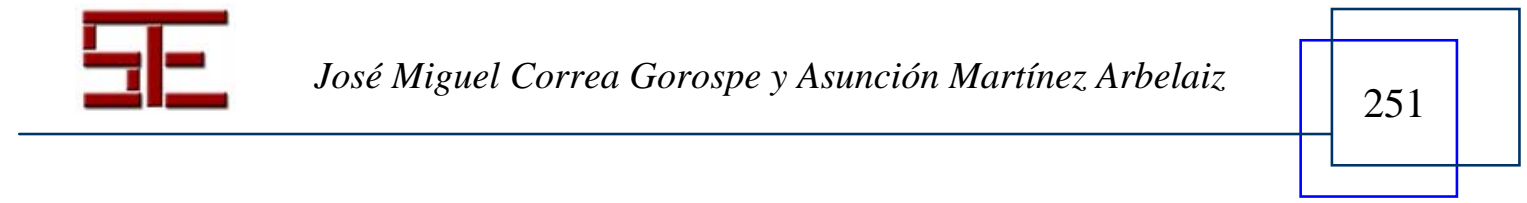




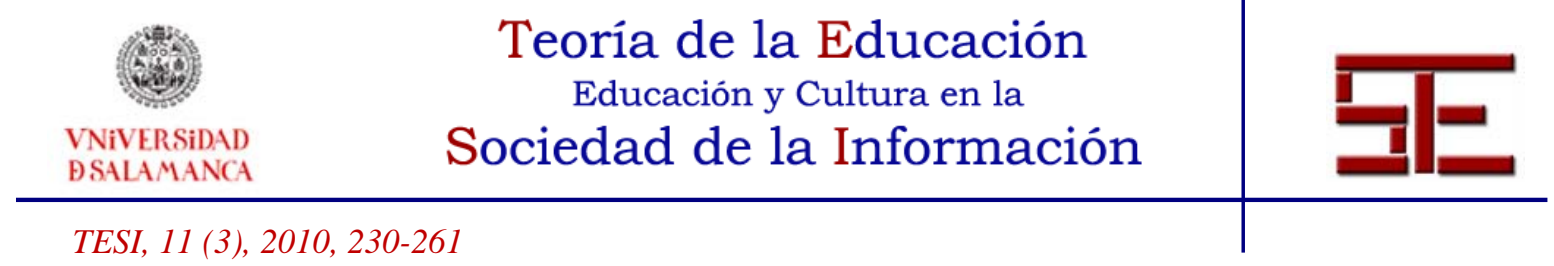

profesora o profesor del colegio, de una hora de duración, abierta para todos los alumnos, los cuales pueden participar leyendo noticias o cuentos.

Las emisiones diarias las organizan y coordinan dos alumnos de segundo ciclo: uno de ellos desempeña el papel de controlador de la radio y otro de técnico. Se cuenta con una programación trimestral, que permite saber qué alumnos son los encargados del trabajo. Por este taller de radio, así como por el resto de talleres los alumnos van rotando. Diariamente se planifica por medio de una ficha las intervenciones en este taller, las cuales suelen consistir en lectura de noticiarios, cuentos, poesías, adivinanzas, trabalenguas, etc.

Durante la jornada escolar la radio está constantemente emitiendo en abierto. Cuando no se emiten intervenciones en directo de los escolares, se escucha música. Los alumnos encargados de este taller se ocupan de dirigir y organizar las emisiones. Si es preciso y consideran que no ha salido correctamente, hacen indicaciones de mejora y animan a repetir la emisión. A continuación describimos dos escenas cotidianas en el taller de radio.

“En el txoko (rincón) de la radio están Nahia y Saioa a un lado, dirigiendo la emisión con los controles y, al otro lado del cristal, haciendo la emisión, Onintze y Jon. Hoy Nahia, que es de tercer curso, es la técnica y Saioa, de cuarto curso, es la controladora. La controladora escribe en la ficha la programación de la radio para el día de hoy. Con los botones de música y micrófono estamos haciendo el programa. Han entrado Onintze y Jon y están leyendo adivinanzas. Seleccionan de un libro las que quieren y las leen. Entre adivinanza y adivinanza la técnica sube el volumen de la música y baja el del micro para que la radio se oiga. El clima en la cabina de emisión es serio, pues los dos alumnos están concentrados en la lectura. Alternativamente leen uno y otra. Leen con interés, mientras en el control, Nahia se maneja con los mandos. Me fijo en la mesa de control y observo que Nahia -la técnica-con los cascos puestos sigue con atención lo que hacen sus compañeros moviendo cuando conviene los mandos del micro o de la música, subiendo o bajando volumen”.

"En la radio Jone es la técnica, tiene 9 años, y es de $4^{\circ}$ de Primaria, está en $2^{\circ}$ ciclo. En el estudio de grabación acaban de leer el "Personaje misterioso" (los alumnos que asisten al taller de radio tienen diferentes hojas con textos variados como chistes, poesías o breves relatos. Cuando no hay otros alumnos hablando por la radio, los dos técnicos seleccionan y escuchan la música, que se oye durante todo el día en el barrio. Hoy ha venido Begoña con tres alumnos sordos. Habían preparado unos textos con descripciones en euskara. Estos alumnos son castellanohablantes pero el texto que han traído para leer era en

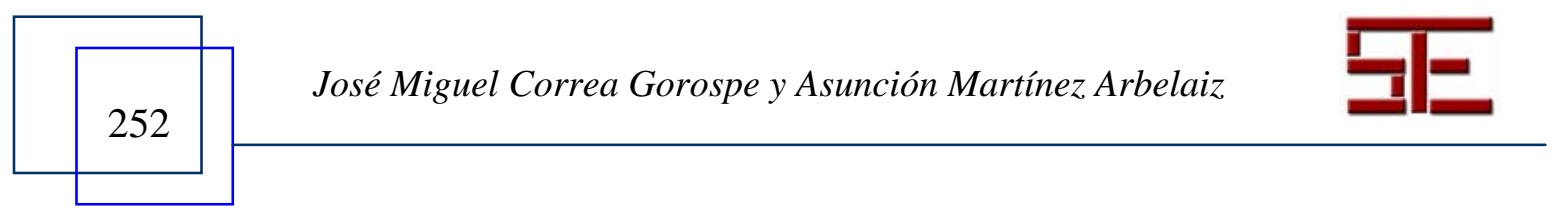




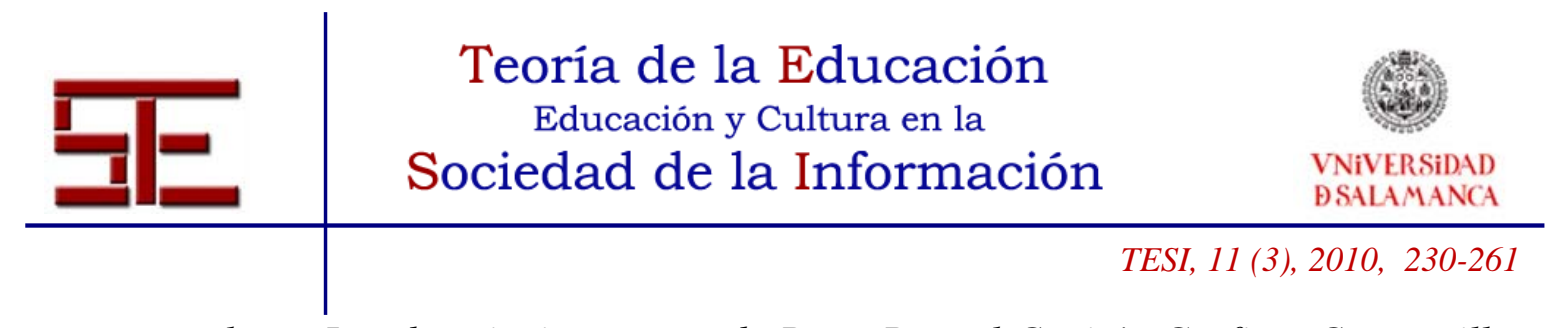

euskara. Las descripciones eran de Peter Pan, el Capitán Garfio y Campanilla. Ellos han entrado en la zona de grabación de la radio y han leído sus descripciones en abierto para el barrio. Otro alumno del txoko de la Txiki-Web ha grabado con el podcast sus voces. Ha sido emocionante oír al alumno leer su texto con esa entonación característica de quiebro en la voz de los niños que tienen dificultades auditivas. Después de grabar con el ipod la lectura en la radio, han llevado la grabación al taller de Txiki-Web. Y les han sacado una foto que han incorporado a la grabación que se publicará en la web."

\section{5.- CLAVES INNOVADORAS EN LA INTEGRACIÓN DE LAS TIC}

Estamos acostumbrados a que se asocie la integración de las TIC con la innovación de la práctica educativa. Sin embargo, observamos que en esta experiencia, donde hay una utilización sistemática, planificada y habitual de las tecnologías en las aulas por parte del profesorado y alumnado, no se le concede ninguna relevancia a la tecnología como indicador de innovación pedagógica. Las TIC se vuelven parte del escenario en el que se desarrolla la actividad diaria sin especial protagonismo.

Lo importante no es la tecnología, sino la identidad y calidad de los procesos de enseñanza-aprendizaje. Como Balastak et al. (2006) señalan en su estudio, las estrategias TIC, para ser efectivas, deben estar integradas en la visión de conjunto de la escuela y ésta es precisamente la coherencia que hemos observado en Amara Berri.

Se trata ésta de una propuesta educativa donde la integración de la tecnología se ha realizado manteniendo su apuesta por un sistema globalizado, intentando superar los tratamientos aislados, parcelados o dicotómicos. En esta propuesta priman los intereses de los niños y sus ritmos individuales; se potencia el ambiente lúdico en el que se imita el mundo adulto, generando así un sistema abierto y no predefinido. Se agrupa al alumnado por ciclos, se organiza el funcionamiento por departamentos y se fomenta el desarrollo de la capacidad crítica y el para qué de las actividades.

Entre otros valores encontrados en la experiencia del Departamento de Medios de Comunicación del Colegio Amara Berri, merece la pena destacarse los siguientes:

- La coherencia de sus actividades con el proyecto pedagógico del centro. Amara Berri, con su propia metodología, ha ido evolucionando desde la utilización de tecnologías analógicas hasta las tecnologías digitales de forma natural y coherente con la metodología que identifica al centro y que le dota de una cultura profesional y pedagógica diferenciada.

- Las actividades se realizan en talleres. No son tareas de simulación, son productos tangibles y con usuarios definidos, tareas cuya finalidad tiene un para qué claro. No son

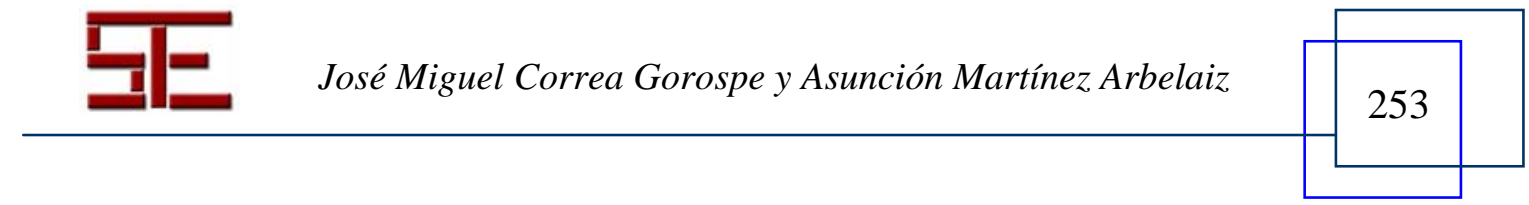




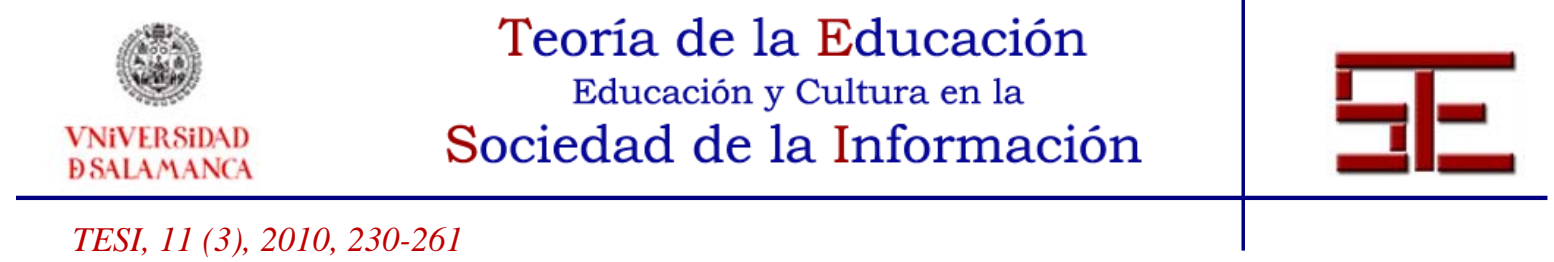

algo temporal ni planificado de forma esporádica, sino que forman parte de la cultura del centro, sostenidas y con una función social. Se trata de una enseñanza activa, donde se actúa, reflexiona y evalúa.

- La conexión y coordinación con las actividades que se desarrollan en otros departamentos. Este aspecto supone un acierto para superar los límites disciplinares de muchas actividades que se realizan con tecnología. Pero esta coherencia no es sólo entre este Departamento de Medios de Comunicación y los demás, sino que es una constante y una exigencia en el centro.

- La dimensión lúdica de las actividades. El realismo está presente en las actividades, puesto que los alumnos tienen la responsabilidad no simulada de sacar adelante una tarea comprometida. Hay una responsabilidad que se espera de los alumnos en el momento de realizar sus trabajos, como antes la tuvieron otros que pasaron por estos talleres y como la tendrán los que vengan. En cualquier caso, esta responsabilidad no está reñida con el disfrute y la dimensión lúdica. Los alumnos distinguen perfectamente los momentos serios de los de distensión, pasando del juego a las tareas más serias mientras exploran las diferentes posibilidades de las tecnologías y nuevas utilizaciones, y roles personales como participantes.

- Naturalidad y realismo de los trabajos que se desarrollan y la responsabilidad de los alumnos y de las tareas que se realizan. Cada medio y producto es un problema que aprenden a resolver, como la edición de la prensa diaria, la página web, la televisión y sus grabaciones, la radio hacia el barrio. Estas tareas aunque están semiestructuradas siempre mantienen un margen amplio de experimentación, de flexibilidad, de creatividad y de complejidad que motiva y huye de la estandarización.

- Una variada gama de herramientas y recursos tecnológicos que facilitan la creación de un contexto de aprendizaje estimulante y rico que va más allá de las necesidades de alfabetización tecnológica.

- Múltiples lenguajes de conocer y representar: euskara, castellano, inglés y la imagen fija, el vídeo, el papel, el audio y la radio, Internet. Son nuevos códigos que plantean nuevos retos a la hora de construir los mensajes, diferentes ámbitos donde iniciarse y desarrollar sus competencias y capacidades comunicativas.

- El trabajo cooperativo y la responsabilidad social de las actividades. Se trabaja en equipo y por parejas pero con una finalidad social. Los trabajos tienen la comunidad educativa como destinataria. Los responsables del taller de Medios de Comunicación trabajan difundiendo no sólo sus producciones sino el trabajo del resto del alumnado.

Lo que editan en la página web y en la revista son los trabajos de todos los ciclos; igualmente en la televisión se graban los trabajos de todos los compañeros del colegio. El hecho del agrupamiento de alumnos por ciclos y no por niveles y la exigencia colaborativa de las actividades multiplican la necesidad de negociación, la flexibilidad cognitiva y empatía para desarrollar las diferentes experiencias que se desarrollan en los talleres. Estos agrupamientos fomentan el co-aprendizaje en la medida que los alumnos

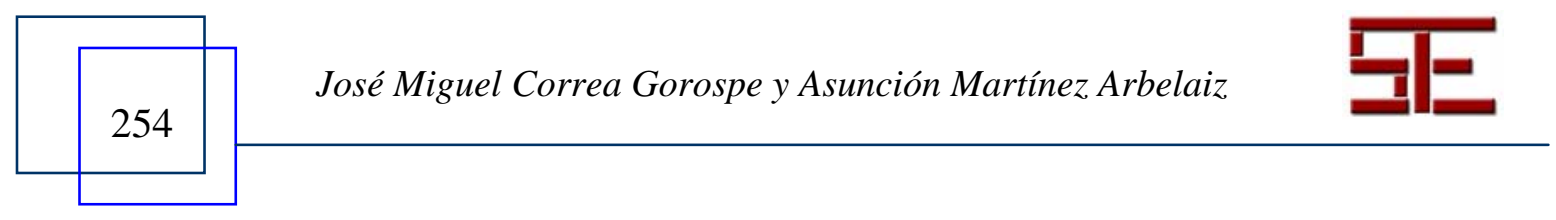




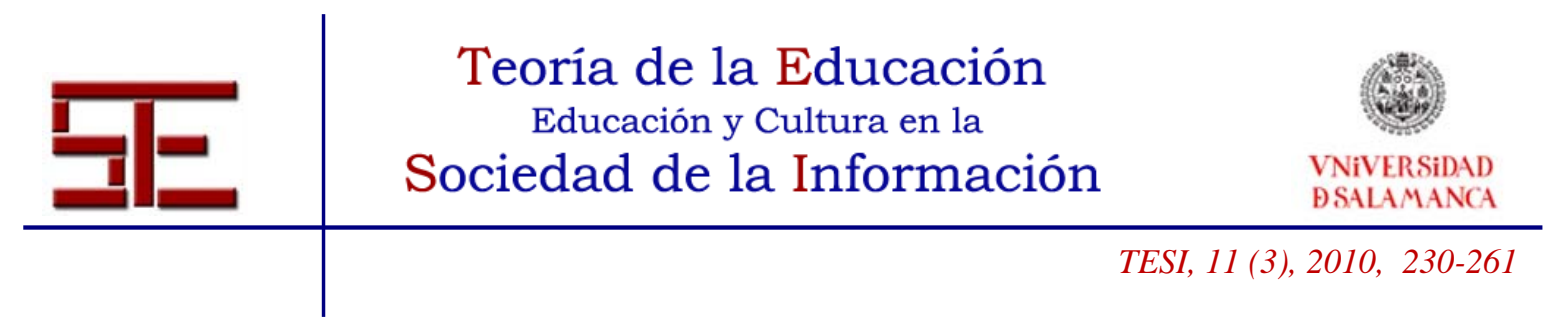

mayores ya han pasado por la experiencia y pueden orientar la realización de las actividades.

Amara Berri cuenta con un proyecto muy orientado a la comunidad y al servicio social. Por lo que se le añade el valor de promover un sentimiento de comunidad. La TxikiWeb, la prensa, la televisión y la radio son productos y realidades culturales que configuran la identidad de un grupo. En estos medios de comunicación se construye la identidad de esta comunidad a través de sus narrativas audiovisuales.

Otro aspecto destacable son las implicaciones en el tratamiento de las necesidades especiales de los alumnos sordos. El protagonismo y relevancia que tiene la lengua de signos y la visibilidad de este colectivo es muy importante.

\section{1.- Papeles innovadores del profesor y del alumno}

En esta experiencia es muy significativo el papel del profesor y del alumno. El profesor dialoga constantemente con los alumnos, les ayuda en la planificación y clarificación de tareas en los diferentes talleres y conjuga orientaciones sobre el trabajo con evaluaciones críticas. De vez en cuando, si hay demasiado ruido o el audio de los ordenadores está alto les pide que lo bajen. Los problemas técnicos con el equipo de aparatos son casi inexistentes. A veces, el canal no está sintonizado en el txoko de la televisión. Su intervención no está orientada a solucionar el problema sino a que el alumno reflexione sobre cuál puede ser el problema, en concreto qué botón hay que tocar para solucionarlo. Su tarea es la de organizador más que de instructor o técnico. Insiste en la realización de las tareas, la organización y la finalización. Mantiene un clima de diálogo con los alumnos. En un espacio como éste donde una gran cantidad de alumnos traen sus trabajos para publicarlos, es necesario organizar este tránsito. Si un alumno desconoce el procedimiento de hacer algo, no se apura y repite el procedimiento, atendiendo a los que traen y preocupándose de que todos tengan protagonismo. Igual ésta puede ser una de las claves personales de su trabajo. Si bien no es suficiente con la participación también se ocupa de la calidad del trabajo. Tiene muy bien interiorizado un modelo de intervención, controla las cuestiones técnicas y su trato con los alumnos se basa en la comunicación y la organización de las tareas. Más que enseñar, muestra caminos; más que imponer, dialoga. El profesor tiene un papel de coordinador y guía. Dialoga con los alumnos y consensúa y supervisa las tareas, cuidando de la organización del contexto de aprendizaje para asegurar las condiciones óptimas. También ayuda, soluciona dudas académicas y tecnológicas.

Los alumnos tienen un rol asignado, el de protagonistas, fomentando su autonomía en el desempeño de sus diferentes tareas. Éstos encuentran un contexto para desarrollar un rol activo y cooperativo. Su implicación es obligatoriamente responsable, realizando una

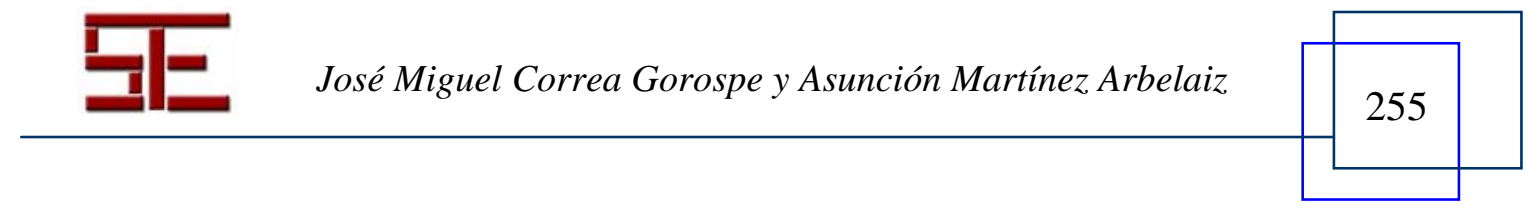




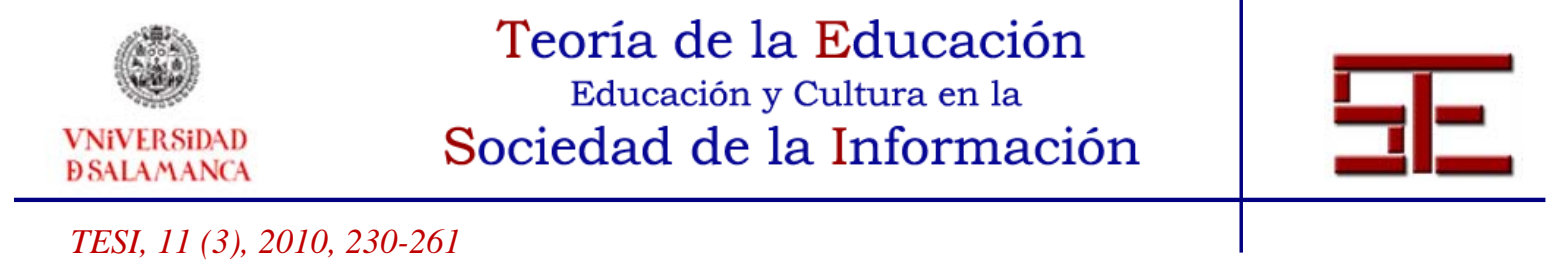

tarea en estos talleres que definen la personalidad e identifican al centro. Por otro lado, la experiencia del Departamento de Medios de Comunicación, como en el resto de Departamentos del centro, exige un funcionamiento cooperativo y en equipo. Las tareas exigen la coordinación con los compañeros del taller para organizar la producción, seleccionar los contenidos, repartir las tareas, etc. La agrupación no homogénea de los alumnos permite que las interacciones entre las parejas o grupos se orienten de manera diferente.

Otra dimensión importante de su actividad es la creatividad y autoría. Los alumnos buscan, comparan, eligen. Ni las tareas, ni las respuestas están en los libros de texto, siempre se mantiene un margen de incertidumbre que obliga a explorar la búsqueda de respuestas diferentes para solucionar las tareas. Por otro lado, los medios digitales permiten dar múltiples respuestas y favorecen el desarrollo de la creatividad al mantener un amplio margen de elección en cómo definimos o finalizamos nuestras tareas, con qué imágenes, música, texto, color, etc.

\section{2.- Las TIC al servicio de la comunidad y de la interdisciplinariedad}

La organización de las actividades tiene tres características importantes:

1. Su clara finalidad de dar salida a las producciones de los estudiantes y a sus actividades. A través de estos medios se vehiculiza las producciones de los diferentes departamentos dándole un especial protagonismo que trasciende los muros de las aulas.

2. En segundo lugar habría que destacar su realismo, la autenticidad de la tarea de aprendizaje. La revista, la web, la radio, la prensa son reales y están sometidas a un tiempo concreto de realización. Los contenidos con los que se nutren todos estos medios no son ficticios, son noticias reales. Además, el contexto de trabajo y la finalidad son auténticos. Las actividades del Departamento de Medios de Comunicación no son un “como si..." sino que cumplen la función real de los medios de comunicación, es decir, difundir contenidos por medio de la palabra y de la imagen. No son problemas que resolver de un libro de texto, sino que la actividad cotidiana y la vida de la escuela les plantea retos y soluciones diferentes que buscar, siendo a la vez estas situaciones variadas y complejas.

3. Esta autenticidad y realismo demanda responsabilidad compartida. Las actividades están sujetas al compromiso temporal de su realización y publicación. Los procesos de aprendizaje crítico de los medios se convierten en un proceso de alfabetización cooperativa. Esta responsabilidad social para con el centro es una responsabilidad compartida. Los encargados de los talleres saben qué se espera y la complicidad es clara; en cada ejemplar, edición o emisión asumen la responsabilidad de que todo salga

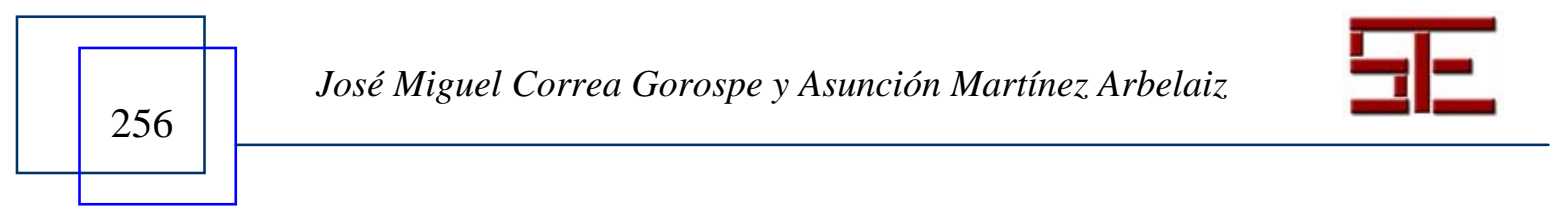




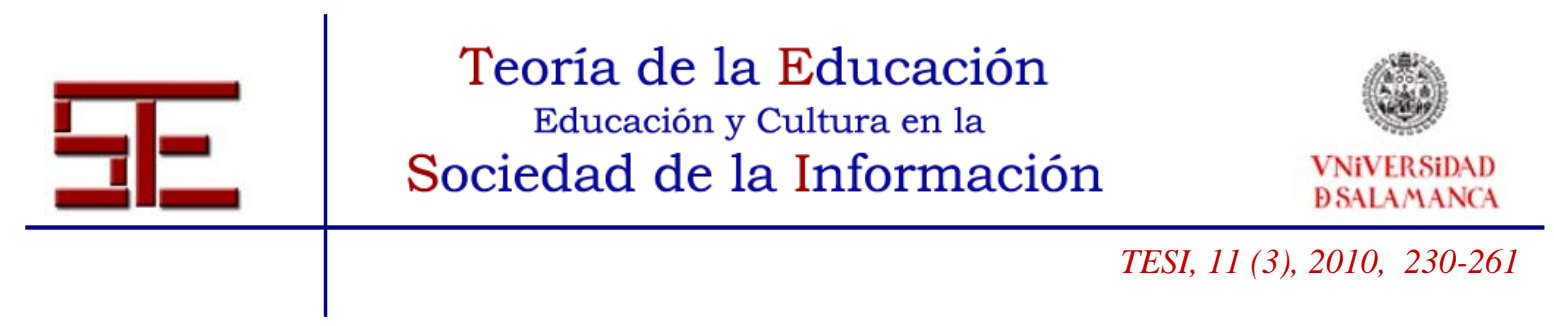

bien. Se ocupan del sonido, de la luz o de las imágenes si están en la televisión. Para los encargados de la Txiki-Web, la responsabilidad es que salgan los trabajos de los más pequeños de forma clara y organizada o los podcast de los alumnos que han pasado por la radio donde han leído un cuento. Las tareas no son repetitivas. No se trata de memorizar, sino de expresar con diferentes medios, comunicar con diferentes lenguajes y movilizar nuestras múltiples inteligencias: en los talleres nos implicamos con nuestra voz, nuestro cuerpo, nuestros sentidos: música, imagen y cuerpo están implicados en los diferentes momentos de las creaciones.

Asimismo, queremos destacar el uso de la tecnología en relación con la responsabilidad compartida o la dimensión ética en el tratamiento de las noticias y selección de contenidos. Hemos reivindicado al comienzo de este texto que las tecnologías no son neutrales, puesto que tienen el potencial de difundir una ideología concreta. Tras revisar las claves pedagógicas de Amara Berri, podemos añadir que la enseñanza de los medios de comunicación tampoco. En este centro han sabido aunar la enseñanza de los medios con un compromiso ético y con el desarrollo del pensamiento crítico. En los contenidos, en el tratamiento de la información, en el diálogo entre los participantes y en la forma de representar, explicar y cuestionar la realidad se fomenta una actitud ética y crítica y se legitima el papel de una escuela comprometida con los problemas sociales. El contenido de las noticias de la televisión que comparten los alumnos es una oportunidad para observar esto. Se observa y se siente en la práctica diaria del centro que los nuevos medios no sólo son más atractivos y motivadores, no son simplemente una cuestión estética o moderna, sino que también pueden ser comprometidos. Este especto ético y crítico se plasma en los contenidos y en la visibilidad de los problemas sociales, en el posicionamiento de los profesores ante la violencia o intolerancia, en el diálogo con los alumnos sobre los problemas sociales y en el espacio y protagonismo que se les ha otorgado.

Por último señalar que en este artículo hemos dado a conocer una parte importante de la experiencia que con tecnología desarrolla el Colegio Amara Berri. Hemos vivido de cerca su práctica y ha sido de gran interés percibir y analizar la respuesta que este centro de reconocida trayectoria innovadora en la Comunidad Autónoma Vasca ha dado al desafío tecnológico. En relación al hilo conductor de nuestro proyecto de investigación sobre el análisis de las políticas educativas TIC y su relación con la innovación educativa, convendría destacar que el modelo de innovación pedagógica y la referencia al uso de las TIC relatada del Centro Amara Berri no están directa ni exclusivamente relacionados con las iniciativas específicas de política educativa para promover el uso de las TIC de forma innovadora o no en las Escuelas del País Vasco sino que ha recibido la influencia de diferentes estrategias de promoción de la innovación a lo largo de estos últimos años. Es, sobre todo, el resultado del trabajo colaborativo y sostenido de profesores de una red de centros que han sabido dar valor y sentido pedagógico a su

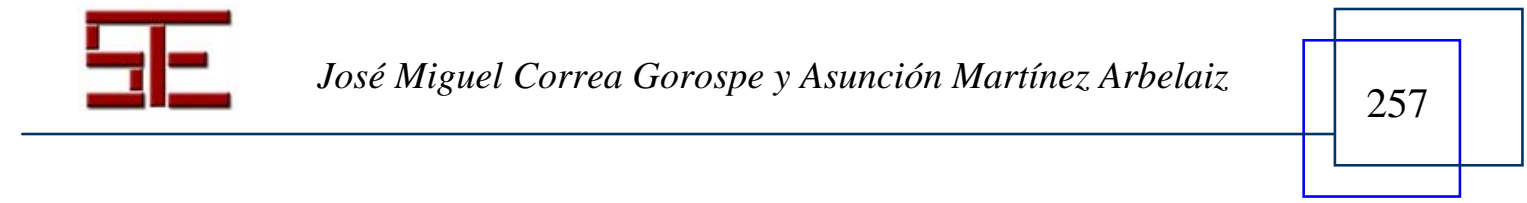




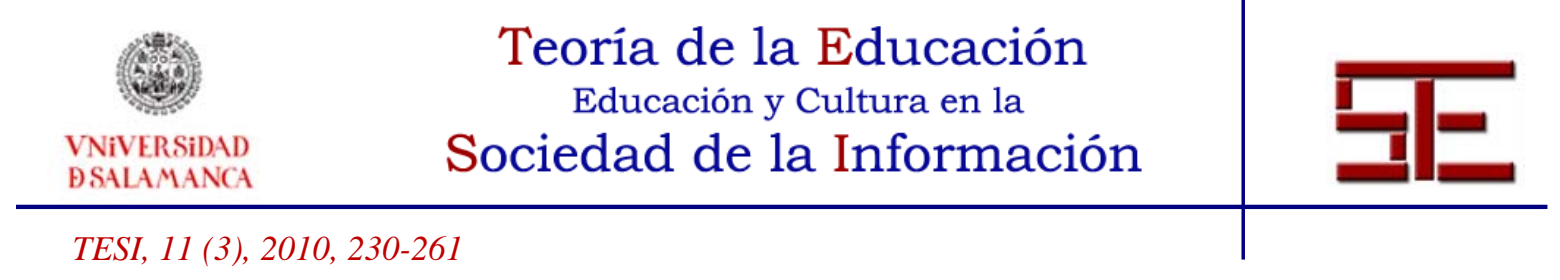

práctica y, siempre desde ese proyecto pedagógico, integrar las tecnologías digitales en su quehacer diario.

\section{6.- CONCLUSIONES}

Terminamos subrayando, por lo tanto, que lo importante a la hora de educar no es la tecnología, sino la identidad y la calidad de los procesos de enseñanza-aprendizaje y la coherencia de sus actividades con el proyecto pedagógico del centro. Las actividades se realizan en talleres, por lo que no son tareas de simulación sino productos tangibles, con usuarios definidos; tareas cuya finalidad tiene un para qué claro y están conectadas y coordinadas con las actividades que se hacen en otros departamentos del centro, realizadas con naturalidad y responsabilidad. El Departamento de Medios de Comunicación cuenta con una variada gama de herramientas y recursos tecnológicos que permiten acceder a múltiples lenguajes para conocer, representar y dar a conocer la realidad, comunicarse o informar. El trabajo cooperativo y la responsabilidad social de las actividades orientadas a la comunidad y al servicio social quedan patentes en las actividades aquí descritas. El sistema pedagógico del centro favorece los roles innovadores del profesorado y del alumnado, permitiendo una evaluación dialogada y constante.

Las tecnologías digitales han encontrado su sitio en el sistema pedagógico de esta escuela de forma coherente con su modelo de innovación pedagógica. El dilema de cómo integrar las TIC se ha resuelto manteniendo una coherencia pedagógica con el modelo del propio sistema Amara Berri, es decir, poniéndolas al servicio del trabajo por talleres, con la agrupación de los alumnos y la organización de los grupos, por medio del trabajo cooperativo, dejando el protagonismo al alumnado, fomentando la autonomía del aprendizaje, subrayando el rol del profesor como guía o como orientador, etc. Eran éstos los principios pedagógicos que sustentaban la identidad y la práctica del centro en la era analógica y que, ahora, con tecnologías digitales, se mantienen y se convierten en pieza clave hacia la innovación.

\section{7.- REFERENCIAS BIBLIOGRÁFICAS}

Anaut, L. (2004). Sobre el sistema Amara Berri. Vitoria-Gasteiz: Servicio Central de Publicaciones del Gobierno Vasco.

Apple. M. (1997). Educación y Poder. Madrid: Paidós.

Area, M. (2008). Buenas prácticas en el uso de las TIC en el aula. [Consultado 12 de febrero de 2009]. Disponible en: http://ordenadoresenelaula.blogspot.com/2008/01/buenas-practicas-en-el-uso-delas-tic.html.

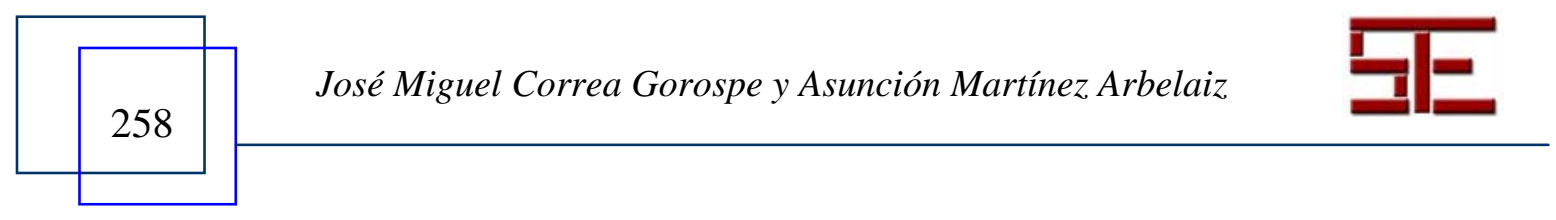




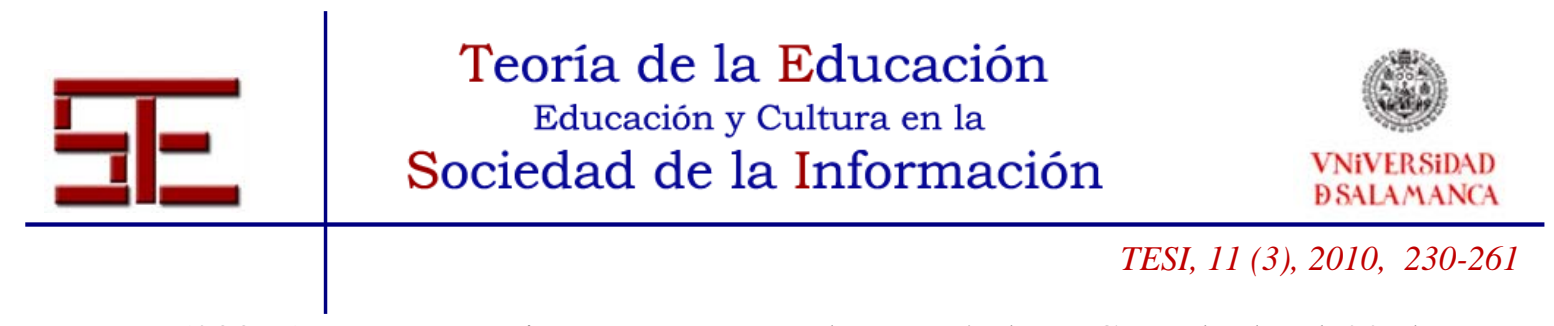

- (2007a). Hoy entrevistamos a Fernando Hernández. [Consultado el 22 de enero de 2009]. Disponible en: http://ordenadoresenelaula.blogspot.com/search/label/entrevistas.

- (2007b). Algunos principios para el desarrollo de Buenas Practicas Pedagógicas con las TIC en el aula. Comunicación y Pedagogía, 227, 42-47.

Balanskat, A., Blamire, R. \& Kefala, S. (2006). The ICT impact report: A review of studies of ict impact on schools in Europe. European Schoolnet European Communities. [Consultado el 16 de abril de 2007]. Disponible en: http:// ec.europa.eu/education/doc/reports/doc/ictimpact.pdf.

Bigum, C. (2002). Sensibilidades de diseño, las escuelas y las nuevas tecnologías de la computación y la comunicación. En Snyder, I. (comp.), Alfabetismos digitales. Comunicación, innovación y educación en la era de la electrónica. Archidona (Málaga): Ediciones Aljibe.

Canales, R. (2006). Identificación de factores que contribuyen al desarrollo de actividades de enseñanza y aprendizaje con apoyo de las TIC que resulten eficientes y eficaces. Análisis de su presencia en tres centros. Barcelona: Universidad Autónoma de Barcelona.

Correa Gorospe, J. M. (2009). El periódico de Amara Berri. Disponible en :http://ia331418.us.archive.org/0/items/abeamaraberrikoegunkaria/prensacastellan o.m $4 \mathrm{v}$.

- (2009). La Televisión Amara Berri. Disponible en: http://www.archive.org/details/latelevisionamaraberri.

- (2009). La Txiki Web del colegio Amara Berri. Disponible en : http://www.archive.org/details/amaraberritxikiweb.

- J.M. (2009). Radio Amara Berri. Disponible en: http://www.archive.org/details/radioamaraberri .

Correa Gorospe, J.M., Jimenez de Aberasturi Apraiz, E., Fernández Olaskoaga, L., Ibáñez Etxeberria, A. (2007). Klik eta Klik y Kosmodisea: Concursos escolares on-line. Comunicación y Pedagogía, 222, 56-60.

De Pablos, J. y Jiménez Cortés, R. (2007). Modelos de buenas prácticas con TIC apoyadas en políticas educativas. Comunicación y Pedagogía, 222, 376-41.

Dede, C. (2000). Aprendiendo con tecnología. Buenos Aires: Paidós.

Fernández Díaz, E. y Correa Gorospe, J.M. (2008). Integración de las TIC en proyectos colaborativos mediante apadrinamientos digitales. Revista Latinoamericana de Tecnología Educativa, 7(2), 57-67. [http://campusvirtual.unex.es/cala/editio/]

Fisher, T., Higgins, C. y Loveless, A. (2006). Teachers learning with digital technologies: a review of research and projects. Disponible en: http://www.futurelab.org.uk/research/lit_reviews.htm\#lr14.

Gee, J.P., Hull, G. y Lankshear, C. (2002). El nuevo orden laboral. Maçanet de La Selva (Girona): Ediciones Pomares.

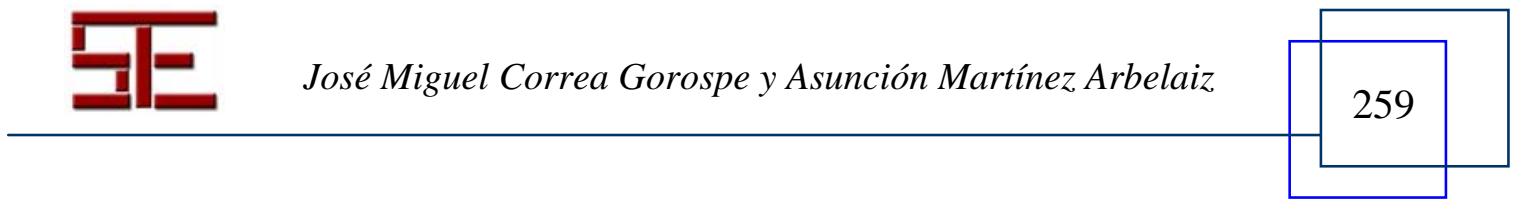




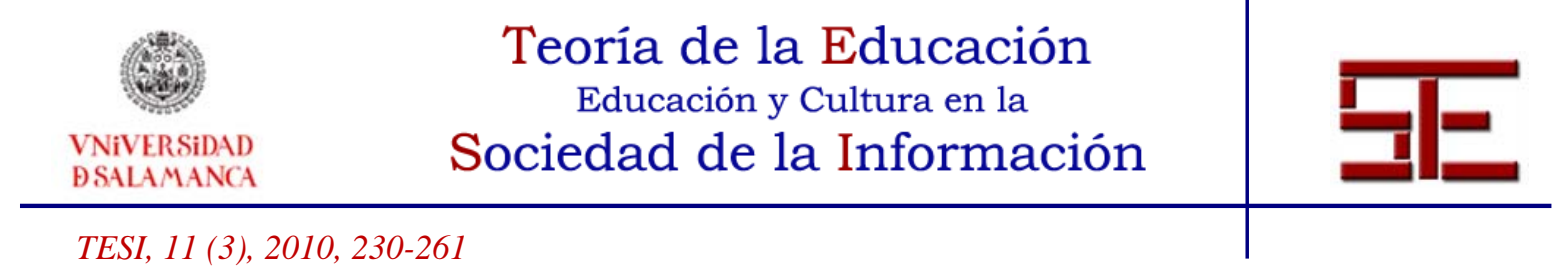

González Ramírez, T. (2007). El concepto de “Buenas Prácticas”: Origen y desarrollo. Comunicación y Pedagogía, 222, 32-35.

Haraway, D. (1995). Ciencia, cyborgs y mujeres. La reinvención de la naturaleza. Madrid: Cátedra.

Hargreaves, A. (2003). Enseñar en la Sociedad del Conocimiento. Barcelona: Octaedro.

Kincheloe, J.L. (2008). La Pedagogía Crítica en el siglo XXI: Evolucionar para sobrevivir. En Mclaren, P. \& Kincheloe, J.L. (eds.), Pedagogía Crítica (pp. 2569) Barcelona: Graó.

Kozma, R.B. \& Anderson, R.E. (2002). Qualitative studies of innovative pedagogical practices using ICT. Journal of Computer Assisted Learning, 18, 387-394.

Lankshear, C. \& Knobel, M. (2008). Nuevos alfabetismos. Su práctica cotidiana y el aprendizaje en el Aula. Madrid: Morata.

Martínez Arbelaiz. A. y Correa Gorospe, J.M. (2009). Can the grammar of schooling be changed? Computers \& Education. Doi:10.1016/J.Compedu.2008.12.016.

OCDE. Definicion y seleccion de competencias claves. Resumen ejecutivo. Disponible en:

http://www.deseco.admin.ch/bfs/deseco/en/index/03/02.parsys.78532.downloadlist.94248 .downloadfile.tmp/2005.dscexecutivesummary.sp.pdf

Pérez Gómez, A. (2008). ¿Competencias o pensamiento práctico? La construcción de los significados de representación y acción. En Gimeno Sacristan, J. (comp), Educar por competencias: ¿Qué hay de nuevo? Madrid: Morata.

Piscitelli, A. (2006). Nativos o inmigrantes digitales: ¿Brecha generacional, brecha cognitiva, o las dos juntas y más aún? Revista Mexicana de Investigación Educativa, 28,179-185.

Riel, M. (2000). La enseñanza y el aprendizaje en las comunidades educativas del futuro. En Dede, C. (2000), Aprendiendo con tecnología. Buenos Aires: Paidós.

Rodríguez Romero, M. (2006). Aprendiendo de la experiencia: los estudios de caso y las perspectivas del aprendizaje y la enseñanza que promueven. Conferencia Internacional OCDE/México. Modelos emergentes de aprendizaje e innovación. Consultado el 24 de enero de 2009. Disponible en: http://academia.unach.mx/planeacion/images/insumos/doctos_internacionales/m odelos_emergentes_aprendizaje_innovacion_7.pdf.

Sancho Gil, J.M ${ }^{\mathrm{a}}$ (2005). Implicaciones pedagógicas de las tecnologías de la información y la comunicación. En VVAA: Didáctica de las nuevas tecnologías de la información y la comunicación. México D.F.: Ministerio de Educación.

Siraj-Blatchford, J. (comp.) (2005). Nuevas Tecnologías para la educación Infantil y Primaria. Madrid: Morata.

Souranta, J. y Valdén, T. (2008). De los medios de comunicación sociales a los medios de comunicación socialistas: el potencial crítico del wikimundo. En Mclaren, P. y Kincheloe, J.L. (eds.) Pedagogía Crítica (pp. 201-226). Barcelona: Graó.

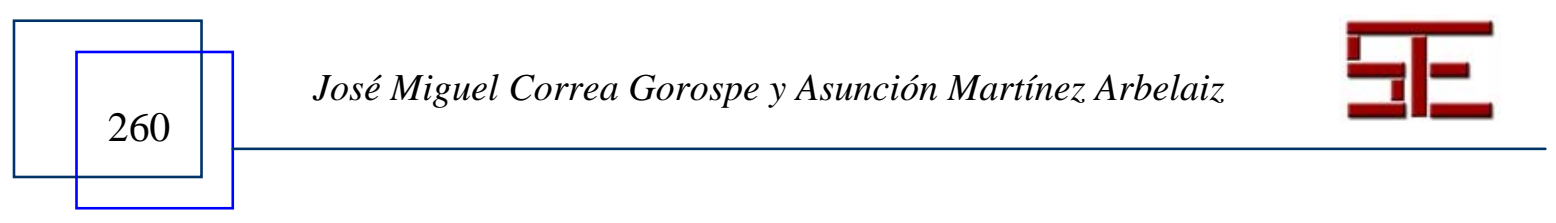




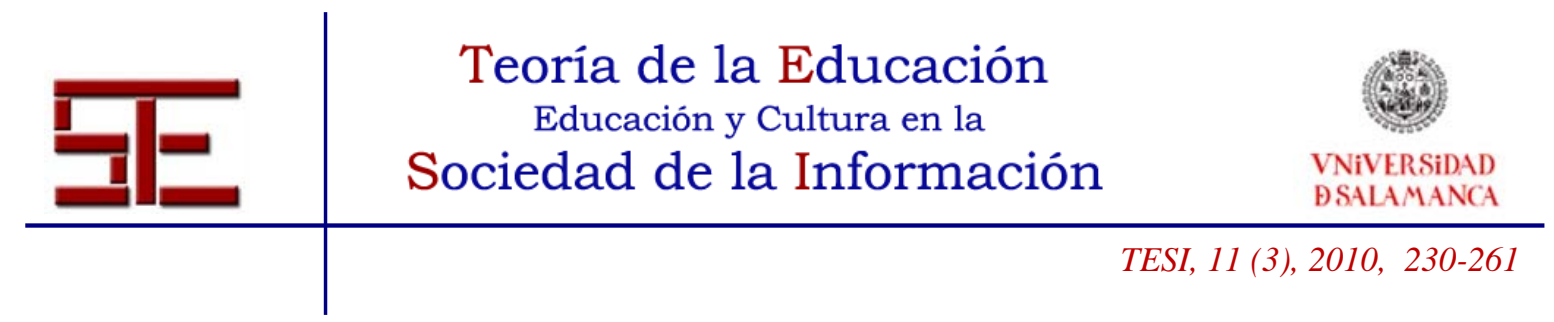

Tyack, D. y Tobin, W. (1994). The "Grammar" Of Schooling: Why has it been so hard to Change? American Educational Research Journal, 31(3), 453-479.

Valverde, J. (2007). El software libre y las buenas prácticas educativas con TIC. Comunicación y Pedagogía, 222, 48-55.

Para citar el presente artículo puede utilizar la siguiente referencia:

Correa Gorospe, J.M. y Martínez Arbelaiz, A.: (2010). “¿Qué hacen las escuelas innovadoras con la tecnología?: Las TIC al servicio de la escuela y la comunidad en el colegio Amara Berri”. En De Pablos Pons, J. (Coord.) Buenas prácticas de enseñanza con TIC [monográfico en línea]. Revista Electrónica Teoría de la Educación: Educación y Cultura en la Sociedad de la Información. Vol. 11, $\mathrm{n}^{0} 1$. Universidad de Salamanca, pp. 230-261. [Fecha de consulta: dd/mm/aaaa].

http://revistatesi.usal.es/ revistas_trabajo/index.php/revistatesi/article/view/5841/5867 ISSN: 1138-9737

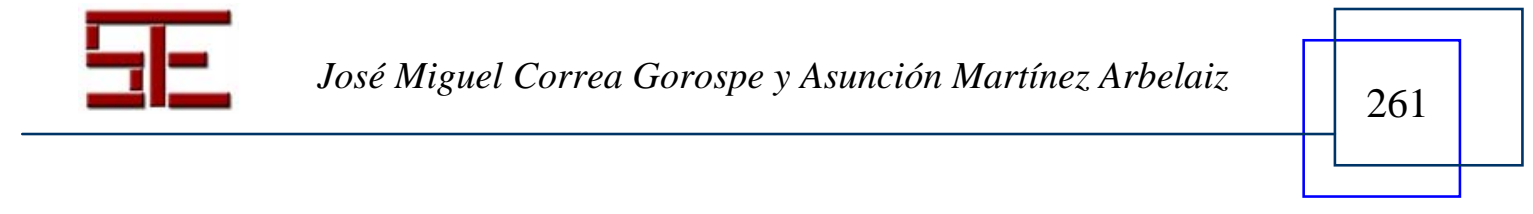

